EARLY EVENTS IN THE ESTABLISHMENT OF AN ASSOCIATIVE SYMBIOSIS OF AZOSPIRTLLUM BRASILENSE' SP 7 WITH GRASS ROOTS

BY

MERCEDES UMAL I-GARCIA

A DISSERTATION PRESENTED TO THE GRADUATE COUNCIL OF THE UNIVERSITY OF FLORIDA IN PARTIAL FULFILLYIENT OF THE REQUIREMENTS FOR THE DEGREE OF DOCTOR OF PHILOSOPHY

UNIVERSITY OF FLORIDA 


\section{ACKNOWLEDGMENT}

The author wishes to extend her sincere thanks and gratitude to the following:

Dr. DAVID H. HUBBELL, for constant encouragement, patience, sincere friendship, and for giving her the chance to appreciate the value of independent work;

Dr. MURRAY H. GASKINS, for the critical evaluation of the different phases of the study, provision of laboratory space and for various forms of support;

Dr. HENRY C. ALDRICH, for useful suggestions in the ultrastructure aspects of the work, and for the challenges which helped her much in making independent decisions;

Drs. REX L.SMITH and STANLEY C. SCHANK, for the intellectual discussions, and for providing experimental plant materials;

Dr. MAX E. TYLER and JAMES R. MILAM, for constructive comments, and for providing experimental bacterial cultures;

Dr. I. VASIL, for making suggestions, and for giving ner the chance to learn the tissue culture technique;

Dr. FRANK B. DAZZO, for guidance in various aspects of the work, especially the biochemical portion, and for the friendship and unsolicited concern;

$\mathrm{Mr}$. STUART PANKRATZ and STANLEY FLEGLER, for the kind and warm accomodation extended her at Michigan State University; 
FACULTY AND FRIENDS in the Department of Soil Science, for their moral and material support;

Mr. VICTOR MORALES, for the interesting intellectual discussions and friendship;

The US-AID, IFAS-University of Florida, and USDA, for the financial support;

The UNIVERSITY OF THE PHILIPPINES at Los Banos, for giving the chance to earn the most coveted training;

Her husband, BENJAMIN M. GARCIA, Sr., for the love and understanding;

Her children, VENER, BENJIE, MINA, JOVEN, RUBEN and BIEN, from whom she draws much needed strength;

TO ALL THESE PEOPLE, this manuscript is dedicated. 
ACKNOWLEDGMENT . .............................. Page

LIST OF TABLES

LIST OF TABLES $\ldots \ldots \ldots \ldots \ldots \ldots \ldots \ldots \ldots \ldots \ldots, v$

LIST OF FIGURES $\ldots \ldots \ldots \ldots \ldots \ldots \ldots \ldots \ldots \ldots \ldots \ldots \ldots \ldots$

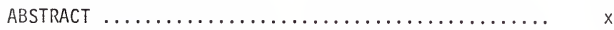

INTRODUCTION $\ldots \ldots \ldots \ldots \ldots \ldots \ldots \ldots \ldots \ldots \ldots \ldots \ldots \ldots \ldots \ldots \ldots$

REVIEW OF LITERATURE $\ldots \ldots \ldots \ldots \ldots \ldots \ldots \ldots \ldots \ldots \ldots$

The Organism ....................... 5

Laboratory and Field Studies ............. 6

Physiology of Interaction ............ 8

Infection Studies ................... 12

MATERIALS AND METHODS ...................... 14

Bacteria and Culture Methods ........... 14

Plant Hosts ........................ 15

Plant-Bacterium Interaction ............ 15

Aseptic Collection of Root Exudate ....... 16

Adsorption Studies ................... 16

Sanning (SEM) and Transmission (TEM)

Electron Microscopy ............... 17

Pectolytic Activity Assay ............... 18

Enzyme Assay $\ldots \ldots \ldots \ldots \ldots \ldots \ldots \ldots \ldots . \ldots \ldots$

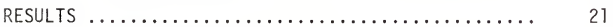

Growth Studies ................... 21

Host-Bacterium Interaction ............. 27

Culture Solution and Root

Morphology ................... 27

Adsorption Studies ................ 34

Binding Snecificity .............. 46

Transmission Electron Microscopy ....... 46

Pectolytic Enzyme Activity ............. 73

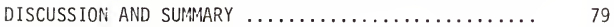

Growth Studies ........................ 79

Host-Bacterium Interaction ............. 80 


\section{LIST OF TABLES}

Table

Page

1. Growth of 6 week old guinea grass inocu-

lated with Azospirizlum brasizense Sp 7 . 33

2. Effect of combined nitrogen $\left(5 \mathrm{mM} \mathrm{KNO}_{3}\right)$ on

adsorption of $A$. brasizense $S p 7$ to

root hairs of pearl millet ......... 37

3. Adsorption of bacteria to pearl millet seedling root hairs .............. 47

4. Effect of pearl millet root exudate on

adherence of $A$. brasizense $S p 7$ to

pearl millet root hairs ( $1 \mathrm{~h}$ incubation). 50 
1. Growth curve of Azospirizzum brasizense in trypticase soy broth (TSB), Okon's succinate medium and in pectin broth .... 23

2. Forty eight hour old $A$. brasizense in TSB, negatively stained with PTA........... 26

3a. TEM photomicrograph of $48 \mathrm{~h}$ cells grown in TSB .........................

3b. TEM photomicrograh of $48 \mathrm{~h}$ cells grown in $-\mathrm{N}$ malate ...................... 25

4. A 5-day old A. brasizense in Okon's mineral medium with pectin .......... 26

5a. Root system of inoculated and uninoculated 1 month old guinea grass ............ 29

5b. Root system of inoculated and uninoculated pearl millet ................ 29

5c. A segment of a root of guinea grass inoculated and grown in $-\mathrm{N}$ medium ...... 30

6. Suppressed elongation of the main root axis

2 days following inoculation with

A. brasizense

7. Dark field photomicrograph of pearl millet root tip inoculated with A. brasizense ... 36

8. Mucigel at maturation region of the pearl

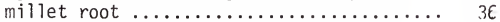

9. Phase contrast photomicrograph of root tip of pearl millet showing boundary formed by bacteria on mucigel ........ 36

10. Dark field photomicrograph of root tip of uninoculated root tip of pearl millet ......................... 36 
Figure

11a. SEM of A. brasizense adsorbed to matured root hairs of pearl millet grown in -is

11b. Higher magnification of similar root hair

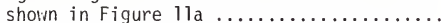

11c. Higher magnification of two of adsorbed bacteria on the root hair surface showing granules common to both ......... 39

12. SEM of A. brasizense adsorbed to the epidemis with mucigel in -N medium

13a. SEM photomicrograph of A. brasizense adscrbed to sloughed cells of pearl millet

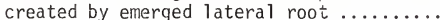

13b. Higher magnification of marked area in

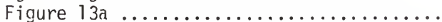

14. SEM photomicrograph of colonization of pearl millet by $A$. brasizense in areas close to void space created by emerging

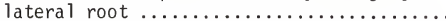

15. Reduced adherence of bacteria to pearl millet root hairs grown in $+N$ Fahraeus medium ....

16. Adherence of azospirilla to epidermal cells of pearl millet roots grown in $+N$ Fahraeus

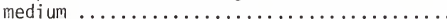

17. Phase contrast photomicrograph of pearl millet root hair inoculated with preincubated $A$. brasizense in root

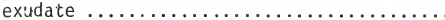

18. SEM photomicrograph of pearl millet root

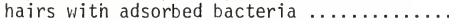

20a. TEly of $x$-section of a root hair from an

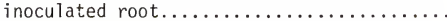

20b. TEli of a x-section of a root hair from an uninoculated root of guinea grass ...... 
21. Root cell wall of pearl millet has staining property as that of the envelope that

enclosed the rhizosphere bacteria ......

22. Two or several azospirilla in a common

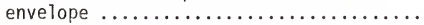

23. Dark field photomicrograph of pearl millet root showing microcolonies associated with mucigel on the root surface and

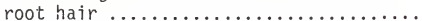

24. Thinning of epidermal walls of guinea grass associated with microcolonies

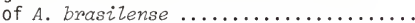

25. Fibrillar material in contact with bacterium on the surface of root cell

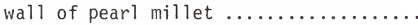

26. A x-section from a matured root of

1 month old uninoculated guinea grass..

27. TEM photomicrograph of a serial

thin section of a root from above the root hair region $\ldots \ldots \ldots \ldots \ldots \ldots$.

28a. Serial thin section in which the root is sectioned and the bacteria are shown outside and inside the middle lamella of the cortical cells after the epidermal layer has sloughed .......

28b. A higher magnification of similar thin section showing bacteria in the middle lamella of the cortical cells .........

29. TEM photomicrograph of a lysed root hair of guinea grass showing entry of

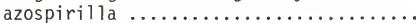

30. A thin section from a section above the root hair region of guinea grass root showing azospirilla in the void space created by emerging lateral root

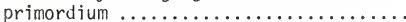

31. Serial thin section of guinea grass root showing middle lamella of cortex with invading azospirilla 
32. Spread of infection of $A$. Brasilense in the middle lariella of cortical tissue of guinea grass root $\ldots \ldots \ldots \ldots \ldots \ldots \ldots \ldots$

33a. TEll photomicrograph of cortical cells from similar root segment as in Figure 32 from an uninoculated guinea grass

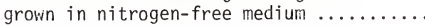

33b. TEM photomicrograph of cortical cells from similar root segment as in Figure 32 and $33 a$ from an uninoculated guinea grass grown in the presence of

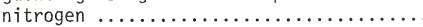

34a. Azospirilla on and inside pearl millet root cell ...................... 70

34b. A high magnification of area marked

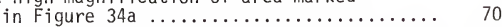

35. Azospirilla with thickened walls enveloped with middle lamellar components of

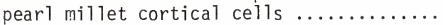

36. Clearing of areas around wells on pectin agar plates suggesting a presumptive pectolytic activity of different fractions obtained from the culture filtrate through $\left.\mathrm{NH}_{4}\right)_{2} \mathrm{SO}_{4}$ precipitation.

37a. Pectin lyase activity of bacterial washing $\left(B_{3}\right)$ and the fifth fraction $\left(F_{5}\right)$ from the culture filtrate .................. 78

37b. The elution profile of the degradation products of the polygalacturonic

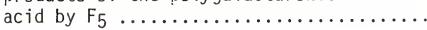




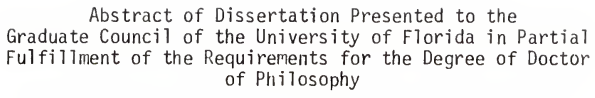

\title{
EARLY EVENTSS IN THE ESTABLISHMENT OF AN ASSOCIATIVE SYMBIOSIS OF AZOSPIRILLUM BRASILENSE SP 7 WITH GRASS ROOTS
}

BY

\author{
Mercedes Unali-Garcia \\ Deceniber, 1978
}

Chairman: Dr. David H. Hubbell

Major Department: Soil Science

The objectives of this study were to document by light and electron microscopy the events leading to the successful establishment of an associative synbios is of Azospirizlum brasiZense $S p 7$ with the roots of a grass host under axenic conditions and to define physiological and biochemical interactions of the association suggested by the ultrastructural studies.

The association between grass roots and Azospirizlum brasizense Sp 7 was investigated by the Fahraeus glass slide technique for axenic plant culture. Young inoculated roots of pearl millet and guinea grass produced more mucigel, more root hairs and more lateral roots than did the uninoculated controls. Within $12 \mathrm{~h}$ after inoculation cells of A. brasizense Sp 7 were embedded in the nucigel at the root cap and along the root axis. The bacteria were also firmly adsorbed to root hairs and epidermal cells but supplementing the medium with combined nitrogen 
reduced the adherence to root hairs. Preincubation in root exudate enhanced ability of the bacteria to attach firmly to root surfaces. The active root exudate factor is non-dialyzable and is inactivated by protease.

Examination of the grass rhizosphere by electron microscopy revealed azospirilla enclosed within a slime layer with high affinity for electron dense materials normally associated with the host root cell wall. The bacteria entered the root tissue through lysed root hairs, open spaces created by sloughing of epiderma? cells and lateral root emergence, and afterward invaded the middle lamellae of underlying cortical tissue. Colonization remained intercellular as long as the adjacent host cells were alive. Clear zones suggesting hydrolytic activity followed the contour of the bacterial cells in the middle larellae. Pectin lyase and endopolygalacturonase activities vere detected in pure cultures grown with purified pectin. This study shows that Azospirizlum brasizense $S p 7$ is capable of limited intercellular infection of the roots of certain grasses. 


\section{INTRODUCT ION}

Potential nitrogenase activity has been reported in grass roots and grass rhizosphere soil of tropical and subtropical grass land and cultivated fields (Neyra and Dobereiner, 1977). The reported nitrogen fixation may be due to Azospirizzum spp. 1/ However, the exact nature of the effect of this bacterium on the growth of grasses is not yet established.

Unlike the Rhizobium-legume symbiosis, Azospirizzum-grass association does not produce visible structures in the roots which indicate successful infection. Studies on sugar cane and Paspalum notatum suggest that the majority of the $\mathrm{N}_{2}$-fixing organisms are closely associated with root surfaces and are probably within the mucigel layer (Dobereiner et al., 1972b). Only light microscope evidence for the physical presence of Azospirizzum on root tissues of plants has been presented. Azospirizzum has been reported to be detected in cortical tissues of Digitaria (Dobereiner and Day, 1974), in cortical and stelar cells of maize (Patriquin and Dobereiner, 1977; Patriquin et a1., 1978; Scott et a1., 1977), and in root hairs, epidermis and xylern vessels of sand grown plants (Lakshmi et al., 1977).

1/ Azospirizzum refers to the free living $\mathrm{N}_{2}$-fixing bacterium that was formerly identified by Dobereiner and Day (1974) as Spirizzum Zipoferum based on Bergey's manual (1957) and on the original description by Beijerinck (1925). However, this manuscript will adopt the more recent genus description, Azospirizzum as proposed by Tarrand et al. (1978), except on reports cited in the previous literature. 
Microbial colonization of root surfaces of field grown sand dune grasses was reported by $01 \mathrm{~d}$ and Nicholson (1975) and of wheat root surfaces by Foster and Rovira (1973). No investigation has yet been carried out under controlled experimental conditions to demonstrate the sequence of events of bacterial infection of young grass roots. Studies on the ultrastructure of the infection process of legumes by Rhizobium have been successful in complementing physiological studies of legume infection. It seemed reasonable to apply the same approach in studying the establishment of the grass-bacteria associations.

The potential application of new $\mathrm{N}_{2}$-fixing systems in agronomic practice as exemplified by the grass-bacteria association is well recognized (Hubbell, 1976). This investigation was, therefore, initiated to present a detailed account of root colonization, root adherence, and infection events in the grassAzospirizlum association as revealed by microscopic techniques and to study the physiological and biochemical interactions of this association suggested by the studies. 


\section{REVIEW OF LITERATURE}

In 1972 Dobereiner and coworkers (Dobereiner et a). 1972a) identified an association of Azotobacter with PaspaZum notatum and calculated that this association could fix $90 \mathrm{~kg}$ N/ha/yr. However, Kass et al. (1971), after a test with diploid and tetraploid varieties of $P$. notatum, indicated that successful establishment of $A$. paspali in the rhizosphere of $P$. notatum grown in sand occurred only with tetraploid varieties, and when the soil was amended with glucose at the time of inoculation. Dobereiner et al. (1972b) reported considerable nitrogenase activity in the roots of sugar cane as well as between the rows. Labelled nitrogen $\left({ }^{15} \mathrm{~N}_{2}\right)$ tracer experiments of sugar cane seedlings grown in soil gave direct evidence of nitrogen fixation associated with the roots. Variations in both the dry weight and nitrogen content among the sugar cane varieties as well as among the individual plants of the same variety were noted (Ruschel et al., 1975).

The rice rhizosphere is also reported to fix an appreciable amount of nitrogen. Yoshida and Ancajas (1971, 1973) have demonstrated that nitrogen fixing activities take place $i$ the root zones of rice plants and in the paddy soil.

Genotypic differences has been demonstrated in several tropical grasses using the excised root assay (Dobereiner and Day, 1974; Day et al., 1975; Dobereiner and Day, 1975; Bulow and 
Dobereiner, 1975). De-Polli et al. (1977) demonstrated nitrogen fixation in two tropical grasses, Paspalum and Digitamia, by ${ }^{15} \mathrm{~N}_{2}$ incorporation.

Another $\mathrm{N}_{2}$-fixing bacterium (unidentified) was characterized by Barber et al. (1976) from roots of Digitaria sanquinalis. Roots of winter wheat (Triticum) and sornhum (Sorghum) have been reported to harbor menbers of Enterobacteriaceae, Kzebsielza pneumoniae, Enterobacter cloacae, and Eminia herbicola, which fix $N_{2}$ in vitro (Pedersen et al., 1978).

A summary of reported rates of acetylene reduction and $\mathrm{N}_{2}$-fixation with the "associative systems" was prepared by Evans and Barber (1977) and Neyra et al. (1977). Neyra et al. (1977) indicated that the most common encountered bacterial species was Azospimizzum. Balandreau and Villemin (1973) and Dobereiner et al. (1972a) pointed out that these grass species possess the $C_{4}$ dicarboxylic acid photosynthetic pathway. Rice (Oryza) was noted as an exception to this general observation.

Brown (1972) and Barea and Brown (1974) suggested that the growth responses of several plants inoculated with Azotobacter paspali were due to the synthesis of plant growth regulating substances by the soil organisms. Indole-3-acetic acid, three gibberellins and two cytokinins were detected in the culture filtrates of this organism. 


\section{The Organsim}

Azospirizlum has been consistently isolated from soil samples collected throughout Germany (Beijerinck, 1925). Soil samples from tropical countries of Africa (Becking, 1963) and Brazil (Dobereiner et al., 1976; Bulow and Dobereiner, 1975) showed the same trend.

The $\mathrm{N}_{2}$-fixing organism which Day and Dobereiner (1974) isolated from $D$. decumbens $c v$. 'Transvala' was identified as Spirizlum Zipofemom. This identification was based on the description of this organism by Beijerinck as reported in Bergey's manual (1957).

In 1976, Dobereiner and coworkers studied the ecological distribution of Azospirizlum and indicated that its occurrence was very much influenced by vegetation. It is isolated in lowest frequency in tropical virgin forest. Azospirizlum could be isolated from soils with a $\mathrm{pH}$ range of $4.0-5.2$.

The physiology and growth requirements of Azospirizzum in pure culture have been well defined by several investigators (Dobereiner and Day, 1975; Okon et al., 1976a, b; 1977; Sampaio et a1., 1978).

A. brasizense grew well and fixed $\mathrm{N}_{2}$ under microaerophilic conditions with malate, succinate, lactate and pyruvate as carbon sources. Its doubling time when supplied with $\mathrm{NH}_{4}{ }^{+}$was $1 \mathrm{~h}$ at $\mathrm{pO}_{2}=0.005-0.007 \mathrm{~atm}$. When grown on $\mathrm{N}_{2}$, the levels of poly$\beta$-hydroxybutyrate and $\beta$-hydroxybutyrate dehydrogenase increased (0kon et al., 1976a). The optimal p02 for acetylene reduction in 
stagnant cultures was $0.006-0.002 \mathrm{~atm}$. depending upon the cell density (Okon et al., 1976a).

Tyler et al. (1977) and Krieg (1977) studied the DNA homology of the different isolates from tropical and subtropical countries. The guanosine/cytosine ratio in these isolates were higher by $5 \%$ than the SpirizZum Zipoferum identified by Beijerinck (1925) and reported in Bergey's manual (1957) and were intermediate between Pseudomonas and Spirizlum (Tyler et al., 1977). Based on the DNA homology series and physiological and growth requirements, it was proposed that the generic name of Spirizzum be changed to Azospirizlum. Azospirizlum was divided into two groups differing in their requirements for glucose and vitamins and in DNA homology (Tarrand et al., 1978). Cells of group II strains were reported to be larger and more pleomorphic than cells in group I. Group I strains utilize $\mathrm{NO}_{3}{ }^{-}$to $\mathrm{N}_{2}$ (Okon et al., 1976a; Sampaio et al., 1978). The ability of Azospirizzum to reduce $\mathrm{NO}_{3}^{-}$to $\mathrm{N}_{2}$ was considered by Neyra et al. (1977) to be very useful for studying various aspects of nitrogen transformation in nature.

\section{Laboratory and Field Studies}

Laboratory and field studies have been carried out to assess the $\mathrm{N}_{2}$-fixing activity of Azospirizzom in several places. Dobereiner (1978) considered that Azospipizzum was most responsible for nitrogenase activity in roots of Digitaria, Panicum, Zea, Triticum and Sorghum in Brazil. 
Nitrogen fixation was reported in a temperate maizeSpirizzum association in low and variable amounts (Sloger and Owens, 1976). However, the amount of $\mathrm{N}_{2}$ fixed was considered to be sufficient for appreciable benefits to uncultivated grasses (Evans and Barber, 1977).

Greenhouse experiments conducted by Gaskins et al. (1977) and Subba-Rao and coworkers (1973) derionstrated yield differences following inoculation.

Field inoculation experiments with pearl millet (Pennisetum americanum) and guinea grass (Panicum maximum) showed that in 3 out of 4 years, Azospirizlum inoculation can induce significantly higher dry matter yields by treated plants (Smith et al., 1976; Bouton, 1977). Further inoculations of plants grown on the sarie sites did not exhibit marked differences in yield from the first experiment. They believed that lack of response to further inoculations may be due to the activity of the surviving Azospirizlum as evidenced by the presence of the bacteria in the samples studied by immunofluorescence (Schank and Srith, pers. conri.). They also have observed differences in response among other species and cultivars. Gahi 3, a pearl millet hybrid, responded significantly to field inoculation. It gave $32 \%$ more dry weight and $37 \%$ more total nitrogen compared to killed inoculum controls (Bouton, 1977). The effect of genotype on response to inoculation with Azospirizlum has also been shown for maize (Barber et al., 1976; Bulow and Dobereiner, 1975); Paspalum notatum, Pennisetum pumpureum and Triticum (Dobereiner and Day, 1975; Smith et a1., 1977 pers. comm.) and for Brachiaria (Pereira et al., 1977). 


\section{Physiology of Interaction}

Azospirizlum was isolated from soils having a wide range pH 4.8 - 7.2 (Dobereiner et al., 1976). More cells occurred on the surface of the roots than in the soil where the plant was growing. The fact that the optirum growth of Azospirizzom in pure culture requires a pH 6.8 - 7.2 (Dobereiner and Day, 1975; Okon et al., 1976a, b) suggests that the plant host may be responsible for maintaining a favorable $\mathrm{pH}$ for the bacteria.

Biological nitrogen fixation, with other components not limiting, is directly related to the amount of carbohydrate available to and utilizable by the microorqanisms as energy source (Graham and Halliday, 1977; Hardy and Havelka, 1976; Streeter and Bosler, 1976; Wheeler and Lawrie, 1976). The role of photosynthate in root exudate on growth of rhizosphere microorganisms has been well documented as reflected in the review of Rovira (1969) and Schroth and Hildebrand (1964). Diurnal variation in nitrogenase activity was observed in bahia grass (Paspalum notatum) and sorghum (Sorghum vulgare) by Dobereiner and Day (1975), in guinea grass (Panicum maximum) and maize (Zea mays) in contrast to rice (Oryza sativa) which did not exhibit any peak at night (Balandreau et al., 1974). It is believed that malate might play a role in the supply of energy for nitrogen fixation, malate being a primary product of $\mathrm{C}_{4}$ photosynthesis (Chollet and Ogren, 1975). However, seasonal changes could have an effect on the population of Azospirizlum in plant roots. Scott et al. (1977) demonstrated no significant change in the number of the organisms throughout the life cycle of 
the plant during summer months while the number went down 10 100 fold during winter.

The stage of the life cycle of the plant has some effect on the variation in nitrogenase activity. In field grown maize, two peaks of nitrogenase activity were observed; the first was during silk emergence and the second was at the start of grain filling (Bulow and Dobereiner, 1975; Neyra et al., 1977). Sorghum was observed to have maximal nitrogenase activity at flowering. In all cases decline of nitrogenase activity was observed at the grain filling stage.

The presence of Azospirizzum only on the root surface and in intercellular spaces of guinea grass and not inside the plant cells of young tissues (Umali-Garcia et al., 1978) suggests dependence of the microorganisms on the root exudate for growth. Gaskins (pers. comri.), by careful analysis of the exudate of several $C_{4}$ grasses, found that simple and complex carbohydrates constitute a major portion of the organic compounds of the root exudate. Carboxylic acids and their derivatives were present in very small amounts. He feels that if Azospirizzum species have to depend on the exudate, the scarcity of the organic acids may limit nitrogen fixation by the bacteria. Azospirizlum has been demonstrated to produce IAA and other plant growth regulating hormones (Tien et al., 1978). The production of growth hormones by Azospirizzum nay be a factor that contributes to the observed differences in yield and root morphology in inoculation studies. The role of IAA in affecting the growth of roots of plants has 
been demonstrated in the studies by Brown (1976) and Barea and Brown (1974).

Increase in nitrogenase activity and number of Azospirizlum in the soil treated with herbicide Alachlor and Atrazin was reported by Marriel and Cruz (1977). Hitrogenase activity was 3 timeshigher with Alachlor and 2 times with Atrazin at $p=0.01$. The mechanism of action of these herbicides on the plant or on the bacteria is not known. However, it should be noted that these have an indole ring in their structure which might be metabolized to compounds having hornonal activity.

Nitrogen fixation in the grass-bacteria system has been commonly detected by measuring acetylene reduction in soil cores and excised roots. Ariount of nitrogen in the plant samples and dry weight are usually determined using intact plants; intact plants are frequently used in the nitrogenase assay. Correlation of results in core assays and preincubated excised root assays is not firmly established as valid (Dobereiner, 1978) although a few reports indicated such correlation (Neyra et al., 1977). Nitrogenase activities in maize and sorghum cores under tropical and temperate conditions were much lower and did not correlate with the excised root assay (Barber et al., 1976; Tjepkema and van Berkum, 1977). Acetylene reduction as a measure of nitrogen fixation was carefully reviewed and evaluated by Gaskins and Carter (1976).

Preincubation at low $\mathrm{pO}_{2}$ overnight prevents the lag usually observed in acetylene reduction assay period; however, 
this usually resulted in increased number of bacteria. A 30 fold increase in the numbers of bacteria in maize roots when incubated at $30^{\circ} \mathrm{C}$ for $24 \mathrm{~h}$ at low oxygen pressure was observed by Barber et al. (1976) while a 100-fold increase was reported by Okon et al. (1976b). It is not yet established whether the Azospirizlum cells localized on the root surface or inside the root tissues contribute to nitrogenase activity (Neyra and Dobereiner, 1977). Combined nitrogen can inhibit nitrogenase activity of Azospirizlum. Neyra et al. (1977) reported that 10 rill $\mathrm{NO}_{3}{ }^{-}$inhibits nitrogenase activity but under anaerobiosis some strains could reduce $\mathrm{NO}_{3}{ }^{-}$to $\mathrm{N}_{2}$. Denitrification was also demonstrated in the field (Eira, 1977).

Heavy nitrogen fertilization could repress nitrogen fixation in sorghum and maize (Barber et a1., 1976), Digitamia decumbens cv. 'Transvala' (Abrantes et al., 1975), rice seedlings (Balandreau et al., 1975), and in wheat (Barber et a1., 1976); Nery et a1., 1977). Nevertheless, addition of a low amount of nitrogen $(40 \mathrm{~kg} \mathrm{~N} / \mathrm{ha})$ at planting time enhanced nitrogenase activity in maize roots (Neyra et a1., 1977), $30-40 \mathrm{~kg} \mathrm{N/ha}$ enhanced activity in guinea grass and pearl millet (Smith and Schank, pers. . comm.) and $50 \mathrm{~kg} \mathrm{~N} / \mathrm{ha}$ in wheat (Nery et al., 1977; Barber et al., 1976). However, the enhanced nitrogenase activity indicated by excised root assays or core assays has not been shown to correlate with assays conducted with intact plants. It is believed that biological nitrogen fixation alone may not satisfy all the nitrogen requirements of grasses and therefore, studies on the 
interaction of combined nitrogen and biological nitrogen fixation and assimilation need further attention. If Azospirizzum must depend on root exudates for their energy supply, it may be necessary to give the host plants a reasonable amount of nitrogen to permit adequate initial growth.

\section{Infection Studies}

The presence of unidentified bacteria on the roots of wheat grown in sand and soil mixture under laboratory conditions was studied using TEM by Rovira and Campbell (1974). They claimed that bacteria were more abundant near root hair region and older roots than at the very tip of the root. The mucigel, when present, showed numerous adsorbed bacteria.

Scanning (SEM) and transmission (TEM) electron microscope were used by $01 \mathrm{~d}$ and Nicholson (1975) to study the microbial invasion of roots of 3 species of sand dune grasses. The bacteria gained entry through perforations in the cell walls or through exposed middle lamellae. They reported that the cortical cells of all the 3 species examined contained vesicular-arbuscular endophyte.

Electron microscopic studies of the wheat rhizosphere by Foster and Rovira (1976) revealed sparse colonization of the young roots but considerable colonization in the outer cortical cells exposed by sloughing and cell wall surfaces of the old roots.

There is light microscope evidence of the physical presence of Azospixizzum in the cortical cells of Digitaria decumbens (Dobereiner and Day, 1974), Zea mays (Bulow and Dobereiner, 1975; 
Patriquin and Dobereiner, 1977) and in Sacchamum officinarum (Patriquin et a1., 1978), based on reduction sites in the cortex of these grasses which were detected following staining with Chloramine T or tetrazolium. Lakshmi et al. (1977) reported light microscope evidence of the colonization of root hairs, epidermis and xylem vessels by Azospixizzum. A preliminary study on the infection of Panicum maximum by Azospirizzum brasizense Sp 7 using TEM in axenic cultures was conducted by Umali-Garcia et a1. (1978). The bacteria entered through lysed root hairs and breaks at point of lateral root emergence and subsequently invaded the underlying cortical cells. The bacteria remained intercellular in the living cortical tissues of the root. A presumptive pectinase activity of Azospirizzum was detected in pure culture. The role of pectinase produced by Azospirizlum in infection of grass roots is not known.

Serological studies of Azospirizzum and other bacteria were conducted by Dazzo and Milam (1976). They found that the age of culture has an effect on agglutination, the 7-day old culture gave the best titer. Incubated sterile roots of guinea grass in goat anti-Azospirizlum antiserum revealed a characteristic flourescence which suggested that guinea grass had common antigens with that of Azospirizzum. 
MATERIALS AND METHODS

\section{Bacteria and Culture Methods}

Azospirizlum brasilense Sp 7 obtained from Dr. J. Dobereiner was used in adsorption and infection studies. For specificity studies the following were used: Azospirizlum brasilense strains Sp $13 t$ and Sp 7 (isolated by J. Dobereiner from Digitaria); JM 125A2 (isolated by J. Milam from Pennisetum), Pseudomonas fluorescens, KlebsielZa pneumoniae, Azotobacter vinelandii UW10, Escherichia coli, (MSU and UF laboratory cultures), and Rhizobium trifolii 0403 (P. Nutman). R. trifolii 0403 was grown in yeast extract mannitol agar (Fred et al., 1932) while the others were grown in trypticase soy (Difco) broth or agar. Pectin broth, which was prepared by mixing $200 \mathrm{ml}$ autoclaved purified pectin (Cooke et al., 1976) at $3.0 \mathrm{~g} / 1$ to $800 \mathrm{ml}$ solution containing the same amount of minerals/ liter described by Okon et al. (1976) fortified with $\mathrm{lg} \mathrm{NH}_{4} \mathrm{Cl}$, was used as the growth medium when the filtrate was needed for pectinase activity analysis.

Growth curves were obtained by growing the bacteria in appropriate media in a side arm flask at $35^{\circ} \mathrm{C}$, and measuring the optical density at wavelengths that gave the least absorbance for the uninoculated medium.

Cells were harvested and washed with isotonic buffer and resuspended to a desired concentration before being used as inocula. 
The morphology of Azospirizlum Sp 7 in different media was studied by examining Gram stained cells under the light microscope and negatively stained cells under the electron microscope.

For negative staining of the bacteria for electron microscope examination, the pelleted cells were fixed in $3 \%$ glutaraldehyde for $1 \mathrm{~h}$ and washed successively with phosphate buffer saline (Dazzo et al., 1976) and deionized water. Cells were dried on 300 mesh Formvar-coated grids and stained with phosphotungstic acid for 3 minutes.

\section{Plant Hosis}

Panicum maximum 285 (guinea grass strain selection by Dr. Rex Smith, Department of Agronomy, University of Florida) and Pennisetum americanum cv. Gahi 3 (pearl millet) were used as plant hosts. Both are small seeded species and therefore suitable for axenic culture of seedlings on glass slide assemblies (Fahraeus, 1957). Both have responded to field inoculation (Smith et al., 1976; Bouton, 1977) with A. brasilense Sp 13t.

\section{Plant-Bacteriun Interaction}

The grass seeds were surface sterilized in $95 \%$ ethanol for 1 min followed by $2.6 \%$ sodiun hypochlorite for $20 \mathrm{~min}$, and washed in 5-6 changes of sterile deionized water. The seeds were left overnight in the last change of water and the procedure repeated the following day. The seeds were then placed aseptically on sterile agar plates and allowed to germinate with plates inverted so that tine radicles would not come in contact with any solid 
surface. When the radicles were about $2 \mathrm{~cm}$ long, they were carefully transferred to autoclaved Fahraeus assemblies (Fahraeus, 1957). In some experiments, this medium was supplemented with $5 \mathrm{mM} \mathrm{Ca}\left(\mathrm{NO}_{3}\right)_{2}$ or $\mathrm{KNO}_{3}$. The slide assemblies were incubated for 1 month in a growth chamber that supplied $80 \%$ of full sunlight, $14 \mathrm{~h}$ photoperiod at $35-36^{\circ} \mathrm{C}$.

\section{Aseptic Collection of Root Exudate}

Surface-sterilized seeds were germinated on a layer of water agar supported by a stainless steel wire in sterile quart Mason jars containing $50 \mathrm{ml}$ of Fahraeus medium. After one veek of incubation (conditions as described above) the sterile root exudate was centrifuged at $8000 \times \mathrm{g}$ for $15 \mathrm{~min}$ and then passed through a $0.40 \mu \mathrm{m}$ filter (Hillipore). The filtrate was either dialyzed against phosphate-buffered saline (Dazzo et al., 1976), ultracentrifuged, concentrated by dialysis against Fahraeus medium containing $20 \%$ polyethylene glycol or incubated at $22^{\circ} \mathrm{C}$ for $12 \mathrm{~h}$ with gentle shaking with protease insolubilized on carboxymethylcellulose (Sigma Chem. Co., St. Louis, Mo.).

\section{Adsorption Studies}

Two separate adsorption experiments were conducted. The first was to test the effect of combined $\mathbb{N}$ on adsorption of $A$. brasilense Sp 7 to pearl millet roots; the second was to determine whether preincubating the cells in root exudate of pearl millet would enhance adsorption of bacteria to roots of the grass host.

For studying the effect of combined $N$, sterile seedlings 
were grown for 2 days in Fahraeus assemblies with and without $\mathrm{N}$ and then inoculated with cells from a $48 \mathrm{~h}$ old culture. For studying the effect of root exudate, the inoculum was preincubated in the collected root exudate solution for $3 \mathrm{~h}$, rinsed with sterile Fahraeus medium and resuspended to a common optical density reading in a nitrogen-free medium. The inoculated seedlings were incubated with gentle shaking for 10 - 30 min in sterile beakers after which the roots were rinsed with sterile Fahraeus medium and examined by phase contrast microscope. Quantitative assessment of bacterial adsorption to the grass root hairs was performed according to a modification of the direct microscope assay of Dazzo et al., (1976). Bacterial cells in firm physical contact with the matured host root hair walls of approximately $200 \mu \mathrm{m}$ in length were considered adsorbed and were counted.

\section{$\frac{\text { Scanning (SEM) and Transmission (TEM) Electron }}{\text { Microscopy }}$}

Rinsed inoculated and uninoculated roots, obtained from adsorption studies, were fixed with $3 \%$ glutaraldehyde in $0.05 \mathrm{M}$ cacodylate buffer, $\mathrm{pH} 7.0$, washed, postfixed with $1 \%$ osmium tetroxide and dehydrated in an alcohol series. Use of small concentration (10 increment) changes for 15 min in each concentration prevented collapse of root hairs. Roots for SEM were subjected to critical point drying (Bomar Critical Point Dryer) and coated with 200 - $300 \AA$ gold in a Film-Vac Sputter coater and examined on an ISI Super III SEM at 15 KV. For TEM, seedlings grown for $1-4$ weeks in Fahraeus assemblies as previously described were harvested 
and rinsed. Root naterials were fixed and dehydrated as above, passed through 3 changes of dehydrated acetone, infiltrated and embedded in Spurr's plastic (Spurr, 1969). U1trathin sections were post stained with lead citrate (Reynolds, 1963) and exarined with a Hitachi HU 11E (75KV) and Philips 300 (80KV) transmission electron microscope.

For acidic polysaccharide staining, Pate and Ordal's (Pate and Ordal, 1967) technique was used while for embedding, Luft's technique was used (Luft, 1961). The roots were prefixed in a mixture containing a $0.5 \mathrm{ml}$ each of $3.5 \%$ glutaraldehyde, $0.2 \mathrm{M}$ cacodylate buffer and rutheniur red stock solution $(1.5 \mathrm{ng} / \mathrm{ml})$ followed by a 10 minute rinse in a $0.15 \mathrm{M}$ cacodylate buffer and fixed for $3 \mathrm{~h}$ in a mixture containing $0.5 \mathrm{ml}$ of $4 \%$ osmiun tetroxide, 0.211 cacodylate buffer and rutheniun red stock solution. Dehydration, infiltration and enbedding were the same as described previously for TEM.

\section{Pectolytic Activity Assay}

Pectin broth was prepared by dissolving and autoclaving 3 grams of purified pectin (Cooke et a 1., 1976) in 200 nl deionized water $(1.5 \mathrm{w} / \mathrm{v})$ and conbining it with $800 \mathrm{~m}$ of the mineral mediun described by Okon et al. (1977). The mediun adjusted to $\mathrm{pH} 7.0$ was inoculated with $10 \mathrm{~m}$ l of inoculum $\left(10^{9} \mathrm{cell} / \mathrm{s} / \mathrm{ml}\right)$ from a $48 \mathrm{~h}$ old culture of A. brasizense Sp 7 in 0kon's defined mineral medium ( Okon et al., 1977). The cells were grown in pectin broth for 7 days at $37^{\circ} \mathrm{C}$, centrifuged, and the supernatant subjected to fractional ammonium sulfate precipitation (0-20, 20-40, 40-60, $60-80,80-95 \%$ saturation). The precipitated fractions were 
dialyzed against a $0.11 \mathrm{i}$ citrate-phosphate buffer at $\mathrm{pH} 5.2$ at $4^{\circ} \mathrm{C}$ in a Spectrapor membrane tubing with a molecular cut off of 6,000 8,000 . The buffer and membrane tubings were changed several times until the fractions were free of sulfate. Aliquots of $0.05 \mathrm{ml}$ from each of the dialyzed fractions were added to wells on pectin agar plates (Cooke et al., 1976) and incubated in an upright position at $37^{\circ} \mathrm{C}$ for $12 \mathrm{~h}$. Tests for pectolytic activity were performed by flooding the plates with either iodide-potassium iodide solution (Dingle et al., 1953) or 1\% hexadecyltrimethyl anmonium bromide (Hankin et al., 1971). Zones of clearing around the wells were considered presumptive evidence for pectolytic activity in the fractions. The bacterial pellet obtained from the same culture was washed 3 times with $5 \mathrm{ml}$ citrate-phosphate buffer and the washings were individually tested for pectolytic activity by the same procedure.

\section{Enzyme Assays}

The procedure used for detection of pectin lyase was modified from that of Lisker and Retig (1974) and Albersheim (1966). A $0.9 \%$ pectin (Sigma grade I) was dissolved in $0.1 \mathrm{M}$ Tris-HCl with $0.002 \mathrm{M} \mathrm{CaCl}_{2}$, adjusted to $\mathrm{pH} 8.3$, and 3 serial dilutions were prepared. A $0.5 \mathrm{ml}$ aliquot from each of the crude enzyme fractions was added to $2 \mathrm{ml}$ diluted substrate and incubated at $30^{\circ} \mathrm{C}$. Measurement of degradation products at $230 \mathrm{~nm}$ was conducted hourly.

To test for polygalacturonase activity, $0.2 \mathrm{ml}$ of boiled and unboiled dialyzed $95 \%$ ammonium sulfate fraction was incubated with $1.8 \mathrm{ml}$ of $0.075 \%$ polygalacturonic acid in $0.02 \mathrm{M}$ citrate 
buffer, $\mathrm{pH} 4.8$ at $30^{\circ} \mathrm{C}$. After digestion for $12 \mathrm{~h}$, the products were fractionated by gel filtration on a column $(1.7 \times 30 \mathrm{~cm})$ of P-2 polyacrylamide gel (Bio Rad Labs., Richmond, Calif.), equilibrated with citrate-phosphate buffer, $\mathrm{pH}$ 5.2. Fractions (200 drops/ tube) eluting from the column were assayed for total carbohydrate by the phenol-sulfuric acid method (Keleti and Lederer, 1974). 
RESULTS

\section{Growth Studies}

Azospirizlum brasilense Sp 7 was grown in TSB ( a rich medium) to serve as a basis for comparison for the growth and morpholoqy of the bacteria in defined media ( e。 q. $-\mathrm{N}$ malate, pectin broth) and in the presence of the host plant. Any morphological changes, therefore, in the rich medium were considered inherent in the organism.

A. brasizense Sp 7 exhibited a normal growth curve in TSB, Okon's medium and in pectin medium (Figure 1). Fastest growth was in TSB. Generation time in TSB was $6 \mathrm{~h}$, the exponential phase began at $2 \mathrm{~h}$ and ended at $12 \mathrm{~h}$.

It grew well in $-N$ pectin broth and $-N$ malate in still culture. The effect of shaking with air on growing Azospirizzum cells in a $-N$ medium was reported by Okon et al. (1976a). The growth curve of $A$. brasizense Sp 7, therefore, was determined only in pectin medium and succinate medium fortified with $1 \mathrm{~g} / 1$ $\mathrm{NH}_{4} \mathrm{Cl}$. The growth of $A$. brasizense $S p 7$ on $+\mathrm{N}$ pectin medium was typical of that in Okon's medium.

The cells grown in TSB were plump rods during the exponential phase and gradually flattened as the stationary phase began. Some cells were attached to each other end to end giving the appearance of a long spiral as described by Dazzo and Milam (1976). 
Figure 1. Growth curve of Azospirizlum brasizense in trypticase soy broth (TSB), Okon's succinate medium and in pectin broth 


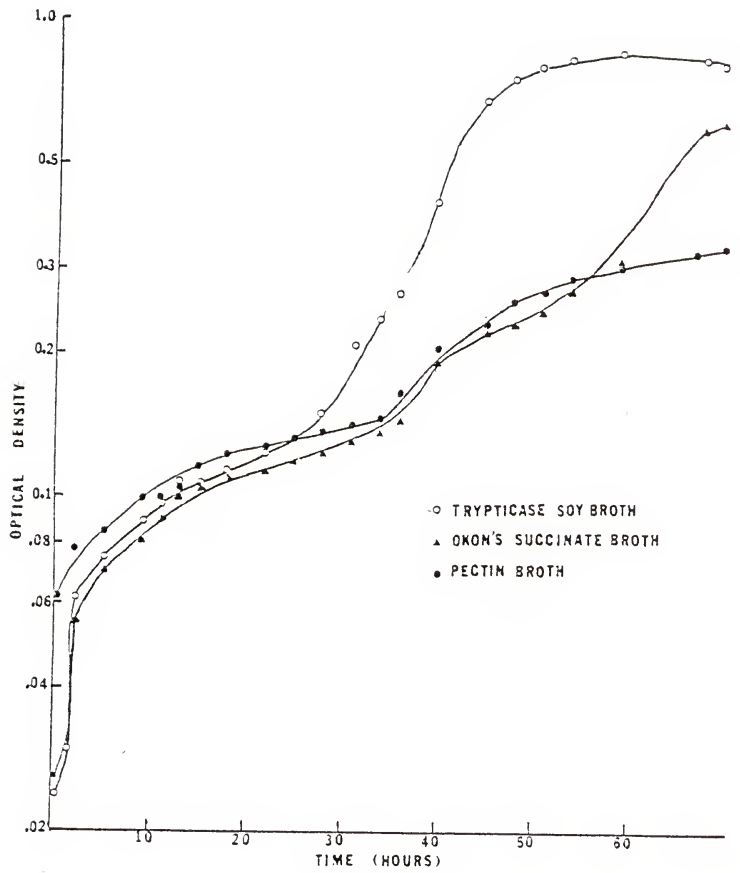


Flocculation and slime production were noted after $48 \mathrm{~h}$ in TSB while in pectin medium this was not seen until after $72 \mathrm{~h}$ 。

In both media, the bacteria appeared as small rods at early exponential phase and gradually increased in size from mid exponential until stationary phase. It was noted that in pectin medium the size of the bacterial cells was variable at $12-48 \mathrm{~h}$ but beyond this the cells became uniform。 At $72 \mathrm{~h}$ and later, the cells were smaller in size and tended to be more rounded than long. Negatively stained $48 \mathrm{~h}$ TSB grown cells revealed the bacteria to be coated by a darkly stained material presumably polysaccharide. Aggregates of $3-4$ or more cells enclosed in a common slime coating were noted (Figure 2a-b). A. brasilense Sp 7 had a single polar flagellum in TSB (Figure 2b). Cells grown in TSB had very dense cytoplasm with only very few electron transparent bodies, poly- $\beta$-hydroxybutyrate (PHB) (Figure $3 a)$. Cells grown in nitrogen free malate had numerous PHB and polyphosphate bodies. (Fiqure 3b). Electron microscopic examination of $48 \mathrm{~h}$ old cells from $+N$ pectin broth revealed dense cytoplasm, prominent qranules and occasional polysaccharide capsules. 01d cultures, as well as cells grown in $-\mathrm{N}$ pectin broth and $-\mathrm{N}$ malate, store PHB. Figure 4 shows an Azospixillum cell with a thin capsular coat. 
Figure 2. Forty eight hour old $A$. brasilense $S p 7$ arown in TSB and negatively stained with phospinotungstic acid (PTA).

a. Four cells aggregated in a common slime matrix $(x 47,500)$

b. An individual cell with a single polar flagellum $(x$ 18,900)

Figure 3a. TEM photomicrograph of $48 \mathrm{~h}$ cells grown in TSB $(X 14,400)$

Figure 3b. TEM photomicrograph of $48 \mathrm{~h}$ old cells grown in -11 malate $(X 31,050)$

Figure 4. A 5-day old cell grown in Okon's mineral medium with pectin. The bacterium has a reticulated cytoplasm (c) with prominent polyphosphate body (ph). The cell wall (arrows) is irregular with thin capsular coat (double arrows). $(x 15,600)$ 


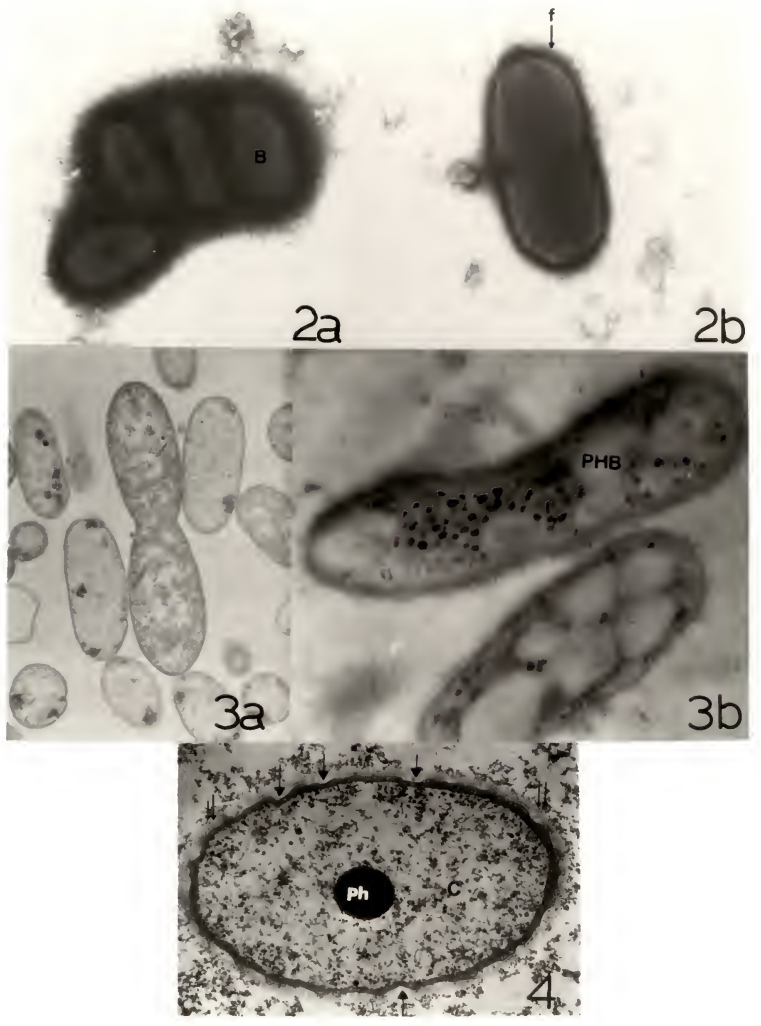




\section{Host-Bacterium Interaction}

\section{Culture Solution and Root Morphology}

The inoculated plant slide cultures became turbid a day following inoculation and remained so until the end of the experiment, indicating the ability of the bacteria to survive and grow in the grass rhizosphere. Roots of uninoculated pearl millet and guinea grass produced few lateral branches and root hairs. In contrast, plants inoculated with A. brasilense Sp 7 produced an abundance of lateral roots (Figure $5 a-b$ ) and root hairs (Figure $5 \mathrm{c}$ ). The effect of inoculation on lateral root and root hair morphogenesis was suppressed by $\mathrm{NO}_{3}{ }^{-}$(Figure $5 \mathrm{a}-\mathrm{b}$ ).

Suppressed elongation of the main root axis of inoculated plants was obvious at 2 days, as shown by the closeness of the root hair region to the meristematic tip (Figure 6) in contrast to the much elongated meristematic tip in the uninoculated controls (Figure 10). Three weeks to 1 month old inoculated plants had more lateral roots than the uninoculated controls (Figure 5a-b). The adventitious roots and branches of the main roots were mostly forked or whorl-like (Figure $5 \mathrm{c}$ ), as compared to less branched roots of the control (see Figure 5a, 5b). Different inoculum levels produced different morphological effects. The highest inoculum level used $\left(10^{9}\right.$ cel1s/20 $\mathrm{ml}$ solution) had longer roots. Roots of plants grown in the culture supernatant of Azospirillum showed the same pattern of shortened lateral roots. The shoots were not as green as those that vere inoculated with live inoculum. 
Figure 5a. Root system of inoculated and uninoculated 1 month old guinea grass. The root system of inoculated $-N$ plant was dense and much branched. The roots of the inoculated but grown in $+N$ plant were comparatively long but less branched than those grown in $-\mathrm{N}$ culture solution. The root system of uninoculated plant was the least dense and had the least branching.

Figure 5b. Root system of inoculated and uninoculated pearl millet. The $-N$ inoculated roots have more root hairs while the $+\mathrm{N}$ inoculated ones have less. 

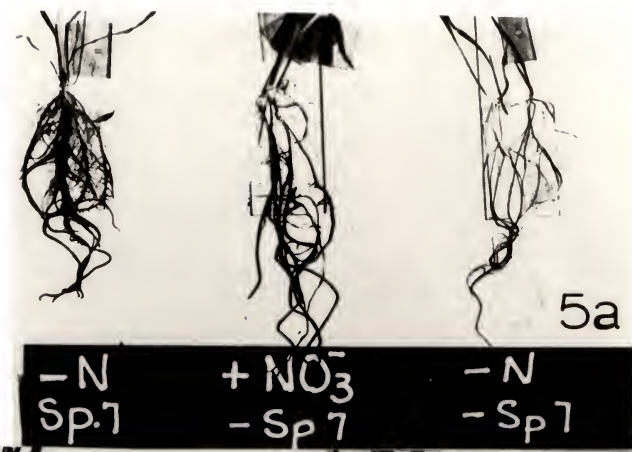

$-N$
$-S_{p} 7$
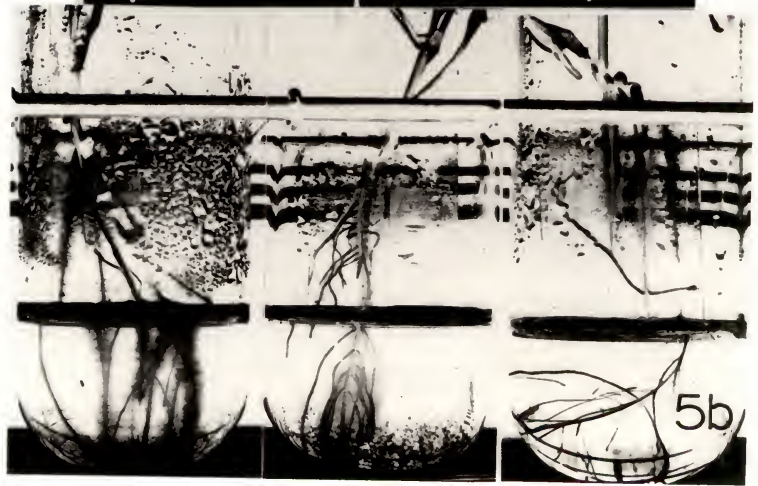
Figure 5c. A segment of a root of guinea grass inoculated and grown in $\mathrm{N}$ culture solution. Note whorl-like type of branching and very profuse root hairs. ( $X$ 750)

Figure 6. Suppressed elongation of the main root axis of of pearl millet 2 days following inoculation with A. brasilense Sp 7 ( $\times 754$ ) 

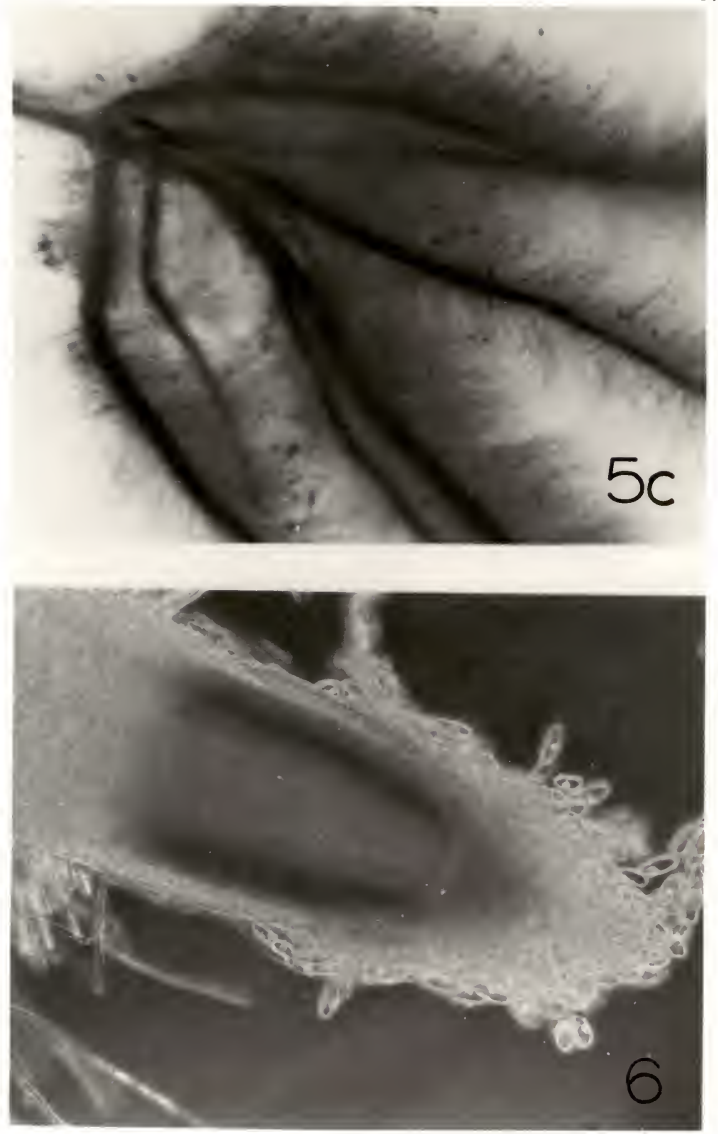
All the plants were stunted under the growth conditions described in the Materials and Methods, although the tops of inoculated plants and those grown in the presence of nitrogen remained green throughout the duration of the experiment except for purple coloration at the base of the leaf sheaths and on the leaf blades. Carbon dioxide may have posed a limitation on the growth of the plants in this closed system. However, the dry weight of 1 month old inoculated plants was higher than the uninoculated controis and comparable to those plants amended with fixed nitrogen (Table 1). Most of the uninoculated controls died before the termination of the experiment. Gaskins (pers. comm.) found that dry weight increases of seedling planis increased as a result of inoculation with aeration, but not comparable to those plants grown in open systems. It may not be safe to extrapolate the results obtained in this experiment to field conditions.

The inoculated roots of both $+\mathbb{N}$ and $-N$ grown plants produced abundant mucigel at the root tip (Figure 7-9) which extended beyond the root hair region (Figure 8). However, the mucigel in the presence of nitrogen was much less than that in the roots grown in the absence of nitrogen. The mucigel in the root tips of $+\mathbb{N}$ grown plants was removed by washing. Numerous azospirilla colonized the slime on the root cap, slime along the root axis, and on the matured root hairs. Bacteria adsorbed in the mucigel formed a boundary in the mucigel around the root cap (Figure 7-9) and root hair region (Figure 8). Rinsing with sterile buffer did not remove the bacteria from the mucigel. The root tips 


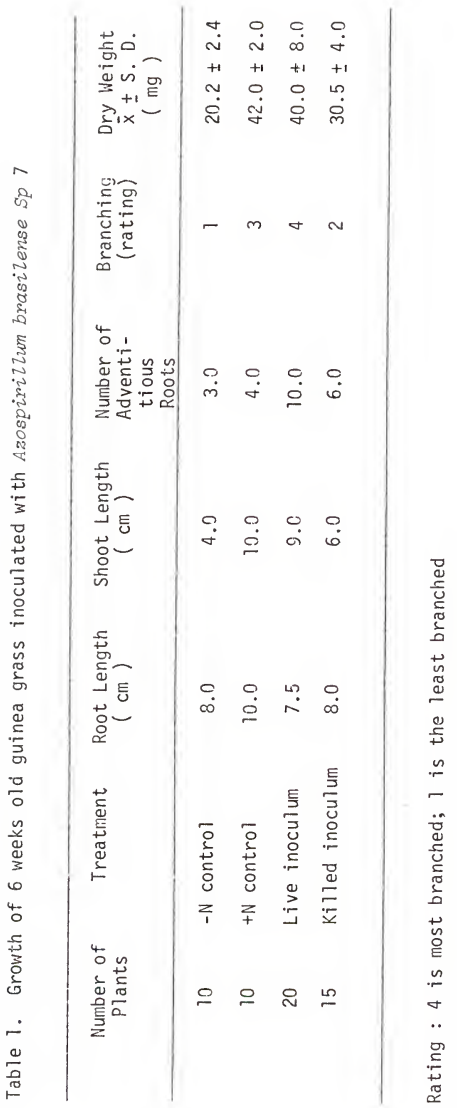


of uninoculated roots produced very little mucigel and were intact (Figure 10), whereas those of inoculated ones had more mucigel and the root cap cells were loose or sloughed (Figure 9). Examination of the culture solution of $-\mathrm{N}$ plants revealed bacterial rosettes and numerous azospirilla attached to the sloughed cells suspended in the culture solution. There was random but prominent bacterial colonization on surfaces of matured root hairs and epidermis. Numerous granules of about $0.15-0.20 \mu \mathrm{m}$ were common on both root hair and bacterial cell surfaces (Figure 11a-c). There was extensive colonization of epidermal surfaces where mucigel was present (Figure 12), of sloughed tissue (Figure 13a-b), and in void spaces created by lateral root emergence (Figure 14). Very few bacteria adhered to the young undifferentiated epidermal surfaces (Figure 13a).

\section{Adsorption Studies}

The age of inoculum had a very pronounced effect on the adsorption of azospirilla to the root hair during a $12 \mathrm{~h}$ period. The $48 \mathrm{~h}$ culture adsorbed most while the 11 day old culture was the least adsorbed. Adsorption occurred in the order of $12 \mathrm{~h}<$ $48 \mathrm{~h}>72 \mathrm{~h} \simeq 5$ days $\simeq 11$ days. When interaction was allowed for a Tonger period, the effect of age on adsorption became insignificant.

Supplementing the medium with either $\mathrm{NH}_{4}{ }^{+}$or $\mathrm{NO}_{3}{ }^{-}$ (5 - $15 \mathrm{mM}$ ) suppressed adsorption of bacteria to root hairs (Figure 15, Table 2) but not to the epidermis (Figure 16). 
Figure 7. Dark field photomicrograph of pearl millet root tip inoculated with $A$. brasizense $S p 7$ Note mucigel (M) layer and azospirilla (arrows) embedded in it. (X 150)

Figure 8 Mucigel (M) at maturation region of the pear 1 millet root. Azospirilla are apparent in the mucigel. ( $x^{\prime}$ 180)

Figure 9. Phase contrast photomicrograph of root tip of pearl millet showing boundary (arrows) formed by bacteria on mucigel (ii). Sloughed root cap cells $(r c)$ are embedded in the mucigel. $(\times 1,200)$

Figure 10. Dark field photomicrograph of root tip of uninoculated root of pearl millet. Root cap (arrows) is intact with practically no

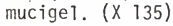




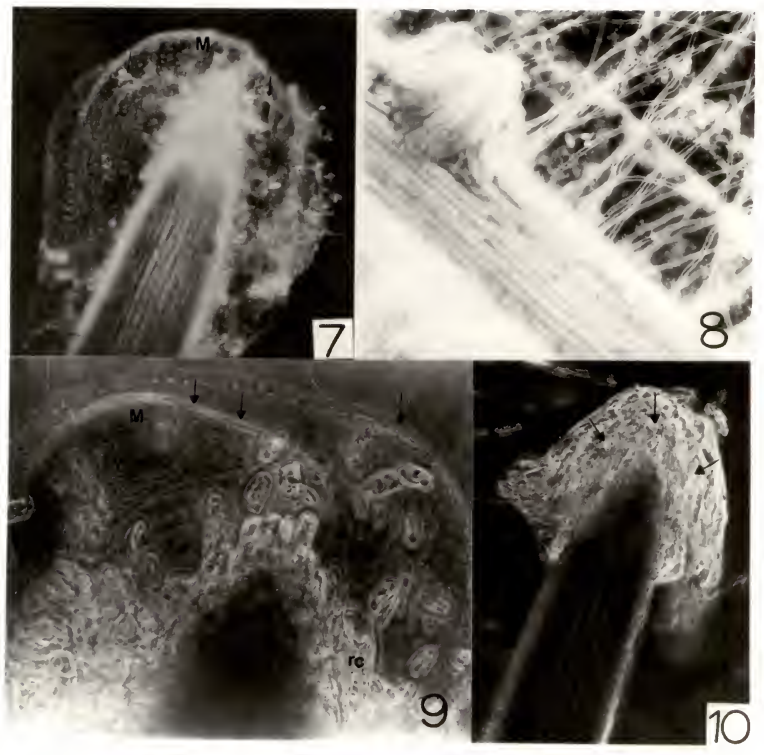


Table 2. Effect of combined nitrogen $\left(5 \mathrm{mM} \mathrm{KNO}_{3}\right.$ ) on adsorption of $A$. brasilense Sp 7 to root hairs of pearl millet cv. Gahi 3

\begin{tabular}{lcc}
\hline $\begin{array}{c}\text { Root Hairs } \\
\text { Counted }\end{array}$ & \multicolumn{1}{c}{ Adsorbed Cells $(\vec{x} \pm$ S. D. $)$} \\
\cline { 2 - 3 }$+\mathrm{N}$ & $-\mathrm{N}$ \\
\hline 80 & $3.15 \pm 0.6$ & $35.0 \pm 10.5$ \\
\hline
\end{tabular}

40 root hairs, each $200 \mu \mathrm{m}$ in length were examined for each treatment 
Ficure 11a. SElf photomicrograph of A. brasilense Sp 7 adsorbed to matured root hairs of pearl millet grown in $-1 \mathrm{~N}$ medium. ( $\mathrm{X} 4,285)$

Figure 11b. Higher magnification photograph of similar root hair shown in Figure 1la. Aggregation of bacterial cells and presence of granules (arrows) on both root hair and bacterial surface are obvious. ( $(X 8,500)$

Figure 1lc. Higher magnification of two of the bacteria on the root hair surface showing granules common to both. (X 15,000)

Figure 12. SEM photograph of A. brasizense Sp 7 cells adsorbed to the epidermal cells with mucigel of pearl millet root grown in $-\mathrm{N}$ medium. $(x \quad 1,181)$ 


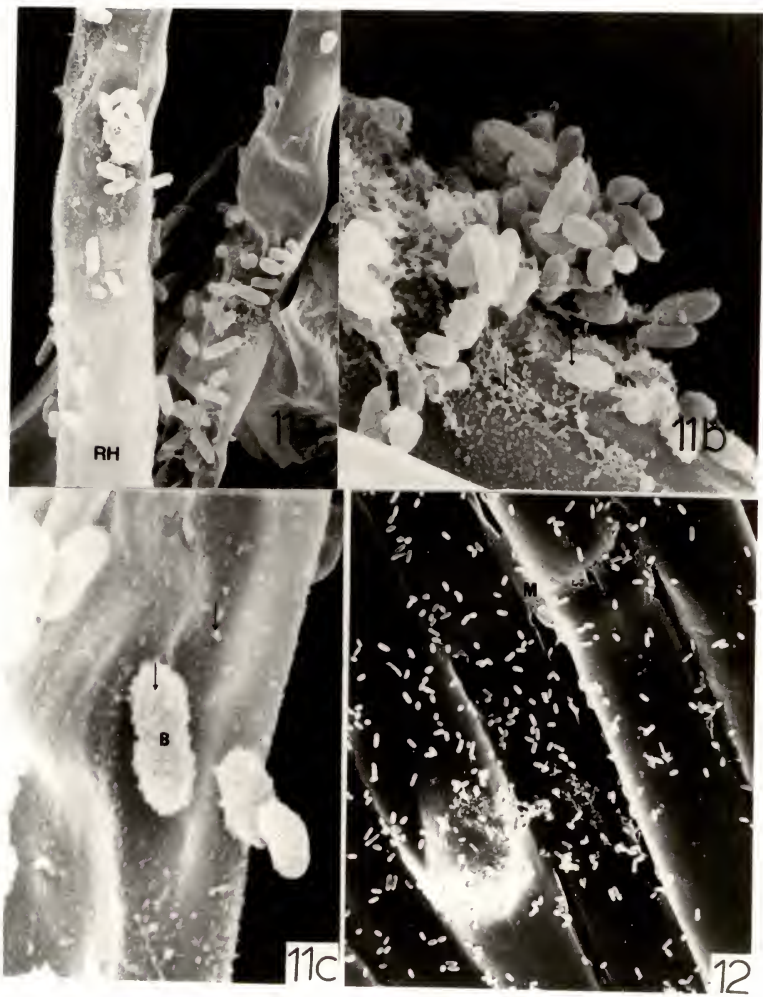


Figure 13a. SEM photomicrograph of A. brasilense Sp ? adsorbed to sloughed cells (sc) created by emerged lateral root $(1 r)$ of pearl millet. Note the absence of azospirilla on the surface of the young lateral root. Marked area shows numerous cel1s on sloughed off tissue. ( $x$ 333)

Figure 13b. Higher magnification of marked area in Figure 13a. The azospirilla (B) are associated with the mucigel on the root surface. $(2,666)$ 

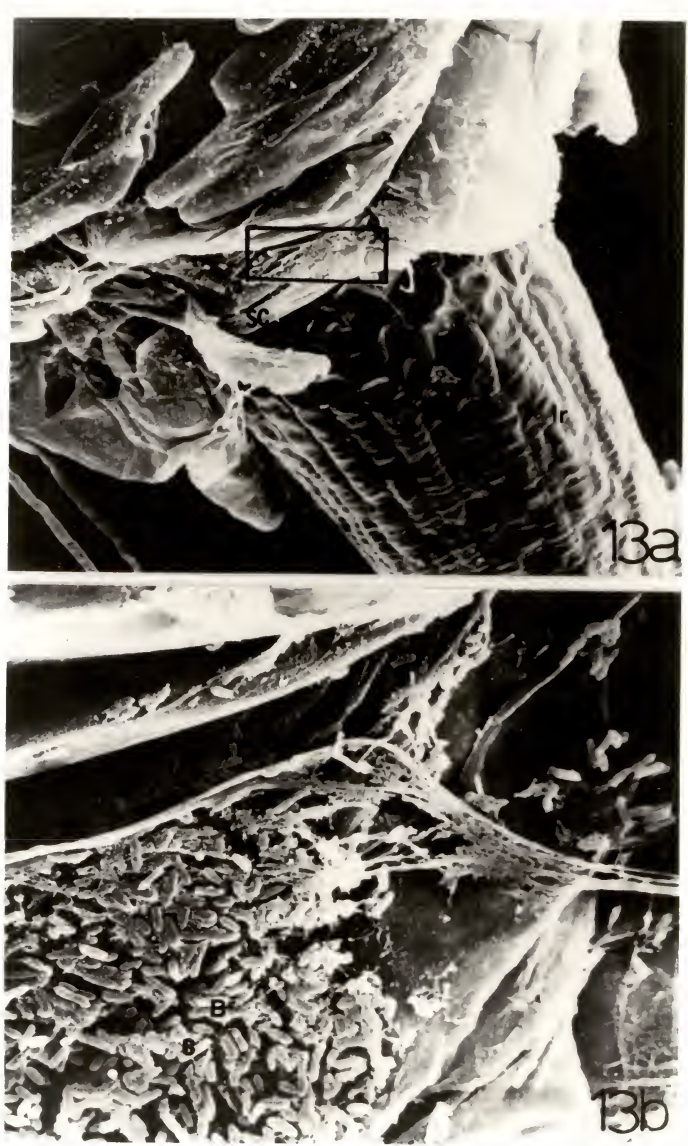
Figure 14. SEM photomicrograph of colonization of pearl millet by $A$. brasilense Sp 7 in areas close to void space (arrows) created by emerging lateral root. $\left(X_{5}, 357\right)$ 


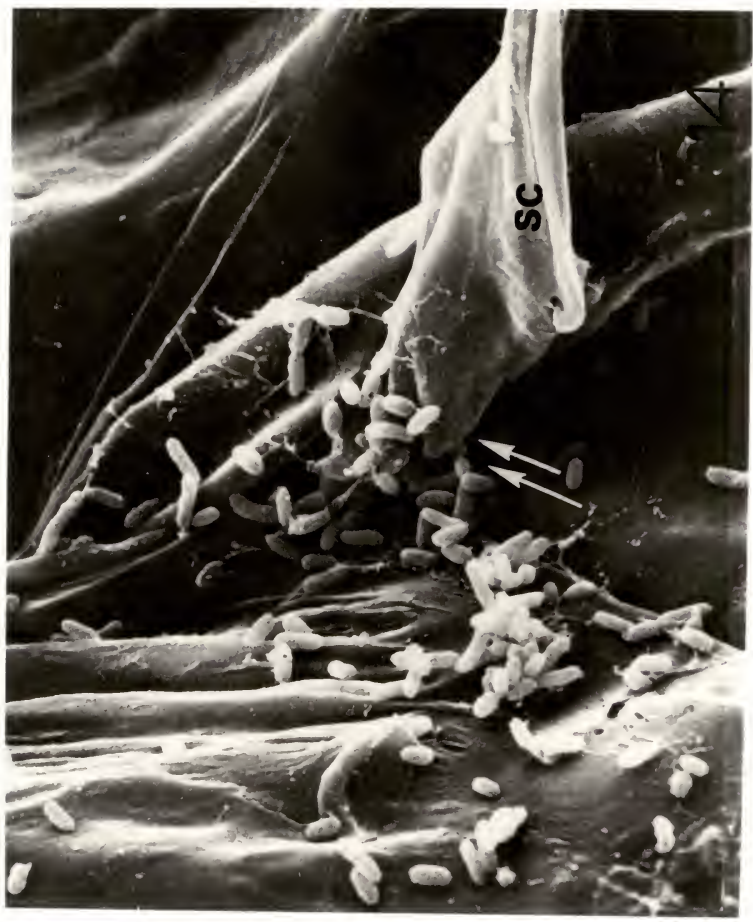


Figure 15. Reduced adherence of bacteria to pearl millet root hairs (RH) grown in $+N$ Fahraeus medium. Note the smooth surface of the root hairs. $(x 3,200)$

Figure 16. Adherence of azospirilla to epidermal cells of pearl millet roots grown in $+N$ Fahraeus medium. As in Figure 12, the azospirilla are adsorbed to the root surface just as well. $\left(x_{1}, 625\right)$ 

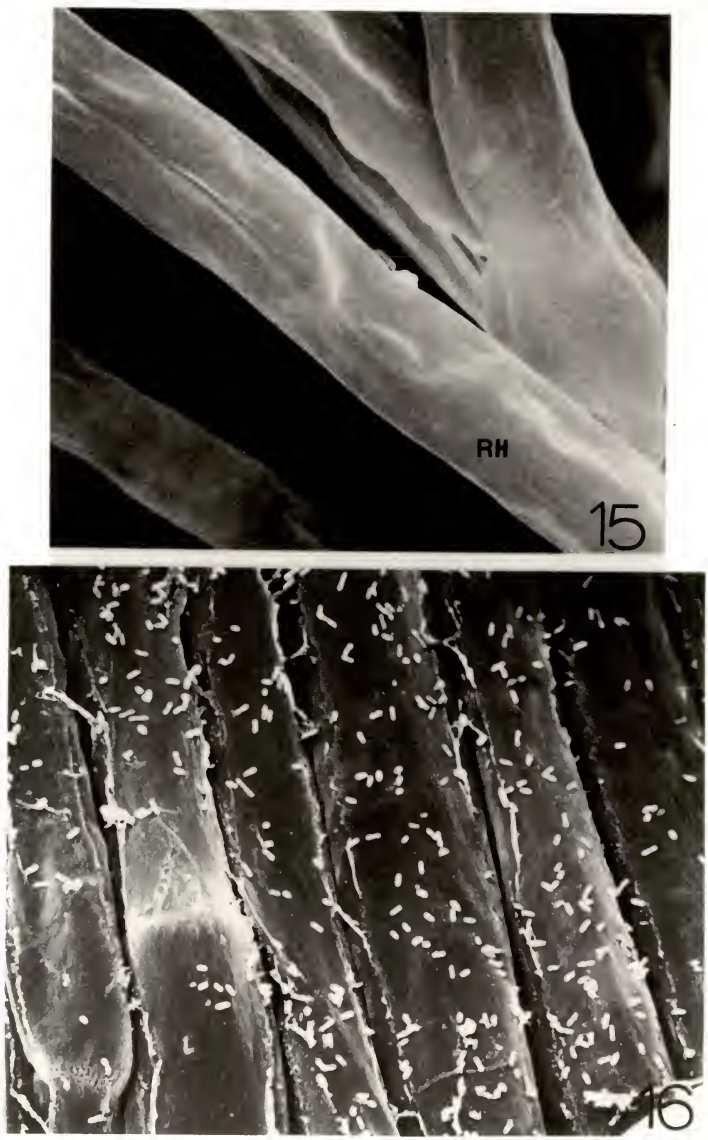


\section{Binding Specificity}

Forty eight-hour old azospirilla bound rapidly to root surfaces. Table 3 shows the trend in binding of the different bacterial species to pearl millet when incubated for 10 - 30 min in $-\mathrm{N}$ Fahraeus medium.

All three of the $A$. brasizense strains tested adsorbed strongly to pearl millet root hairs. $R$. trifolii 0403 and P. fluorescens adsorbed to root hairs but less firmly than A. brasizense. A. vineZandii UW10, E. coli and $K$. pneumoniae did not adsorb to the root hair surface.

Preincubation of $A$. brasizense cells in pearl millet root exudate promoted their firm adherence to the root hair surface (Figure 17, 18, 19; Table 4). This root exudate factor was inactivated by protease and was non-dialyzable. Bacteria which had been preincubated in root exudate previously dialyzed against $20 \%$ polyethylene glycol showed greatest adsorption to pearl millet root surfaces. Bacteria that had been preincubated in proteasetreated root exudate showed very little tendency to adsorb to the roots. Clumping made it hard to quantitate observations, hence adsorption was rated on a 1 - 5 scale. Azospirilla did not bind root hairs of pearl millet which had been placed in steam bath for an hour.

\section{Transmission Electron Microscopy}

Electron dense granules approximately $0.20 \mu \mathrm{m}$ in diameter were evident in the granular matrix of the mucigel on the root surface (Figure 20a), in contrast to the almost smooth root hair surface of the uninoculated root (Figure 20b). 
Table 3. Adsorption of bacteria to pearl millet seedling root hairs

\begin{tabular}{|c|c|c|}
\hline Bacteria & $\begin{array}{l}\text { Root Hairs } \\
\text { Counted }\end{array}$ & $\begin{array}{l}\text { Adsorbed Cells } \\
\bar{x} \pm \text { S. D. }\end{array}$ \\
\hline Azospirillum brasilense Sp $13 \mathrm{t}$ & $3 t \quad 16$ & $23.7 \pm 2.4$ \\
\hline A. brasilense Sp 7 & 18 & $33.0 \pm 4.0$ \\
\hline A. brasilense Sp JM125A2 & 19 & $32.5 \pm 2.9$ \\
\hline Pseudomonas fluorescens & 15 & $11.4 \pm 1.3$ \\
\hline Rhizobium trifolii 0403 & 19 & $14.4 \pm 2.0$ \\
\hline $\begin{array}{l}\text { Azotobacter } \\
\text { vinelandii UW10 }\end{array}$ & 15 & $0.6 \pm 0.3$ \\
\hline Klebsiella pneumoniae & 18 & $0.3 \pm 0.2$ \\
\hline Escherichia coli & 16 & $0.06 \pm 0.06$ \\
\hline
\end{tabular}

1/ Mean of 2 replicates 
Figure 17. Phase contrast photomicrograph of pearl millet root hair inoculated with preincubated $A$. brasilense Sp 7 in root exudate. Some bacteria are attached end to end (arrows). $\mathrm{RH}$ - root hair; B - azospirilla $(x) 1,400)$

Figure 18. SEM photomicrograph of similar root hair as in Figure 17. The undifferentiated epidermal cells are not as affected as the root hair. ( X 1,200)

Figure 19. SEM photomicrograph of pearl millet root hairs ( $\mathrm{PH}$ ) with adsorbed bacteria. Some root hairs (background) appeared lysed. $($ X T,120) 


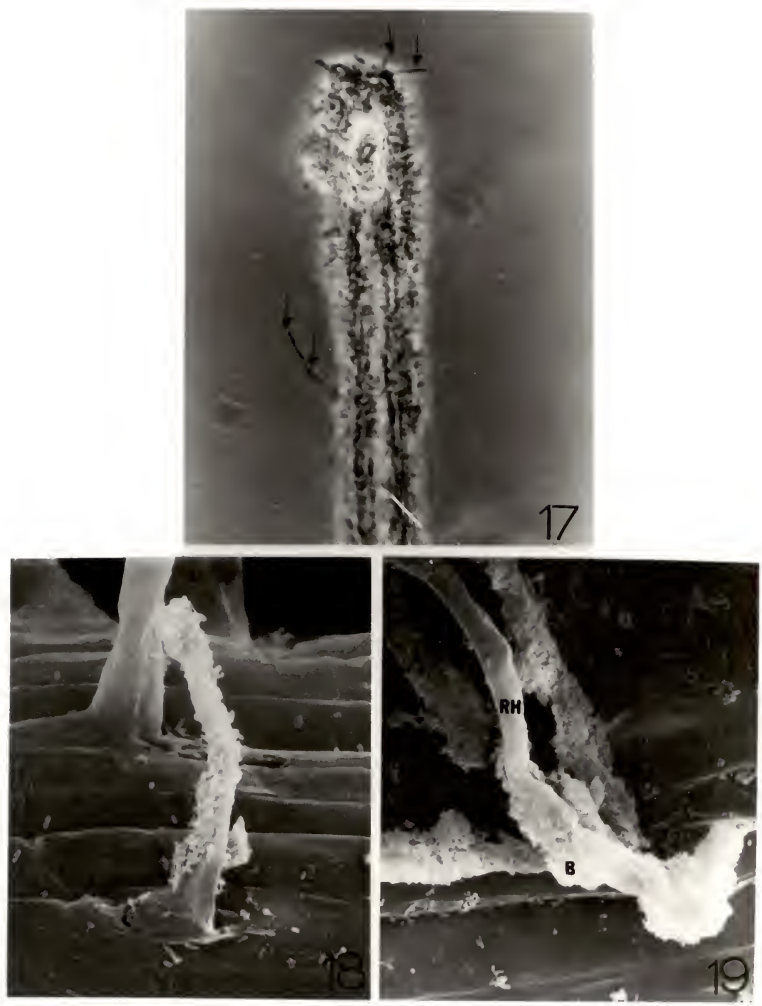


Table 4. Effect of pearl millet root exudate on adherence of A. brasilense Sp 7 to pearl millet root hairs $(1 \mathrm{~h}$ incubation)

$$
\text { Root Exudate }
$$

$$
\begin{aligned}
& \text { Specific Activity Rating } \\
& (u g \text { protein/ml) }
\end{aligned}
$$

\begin{tabular}{lcc}
\hline Dialyzed & 10.5 & 4 \\
U1tracentrifuged & 17.5 & 4 \\
$\begin{array}{l}\text { Unconcentrated } \\
\begin{array}{l}\text { Dialyzed against } \\
\text { polyethylene glycol }\end{array}\end{array}$ & 13.5 & 5 \\
$\begin{array}{l}\text { Fahraeus medium (-N) } \\
\text { Incubated with protease }\end{array}$ & 56.0 & 1 \\
\end{tabular}

5 is most adsorbed; 1 is least adsorbed 
Figure 20a. TEM photomicrograph of $x$-section of a root hair from an inoculated root grown in nitrogen-free medium. Dark granules (arrows) are on the surface of the root hair. (X 10,514).

Figure 20b. TEM photomicrograph of $\mathrm{x}$-section of a root hair from an uninoculated root of guinea grass grown in nitrogen-free medium. The dark granules seen in Figure 20a are absent. (X17,265) 

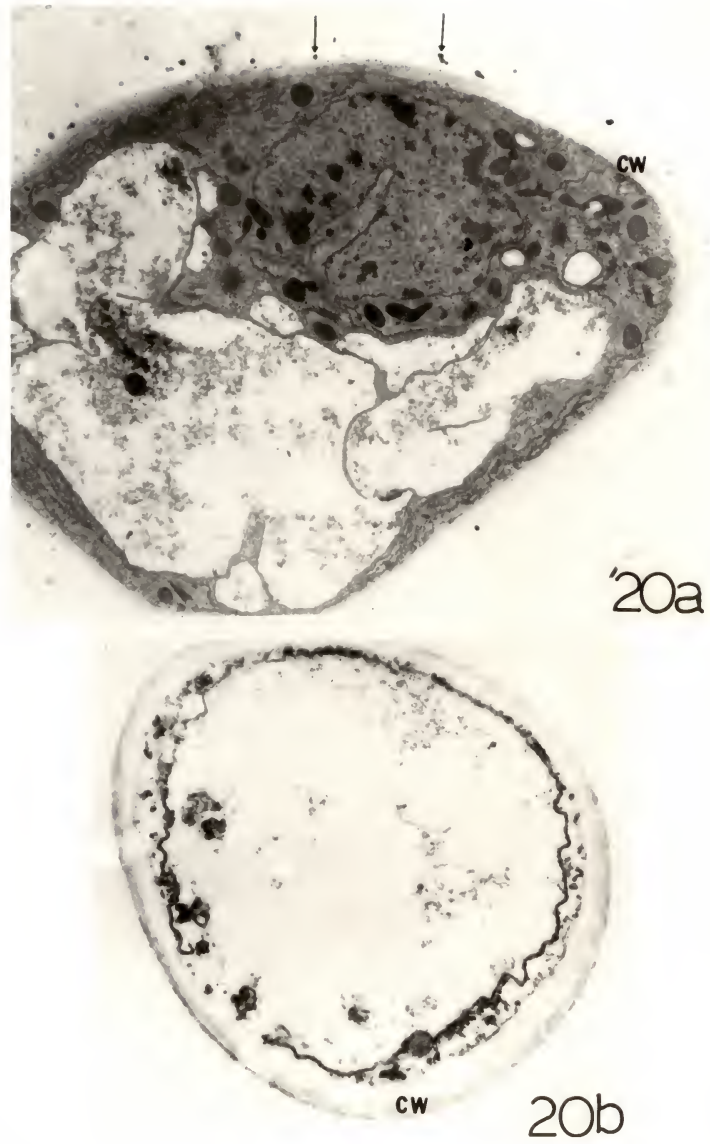
Groups of 2 - 4 bacterial cells were enclosed in a slime envelope, the electron density of which was close to that of the root cell wall (Figure 21, 22). Random microcolonies were associated with the mucigel on the root surfaces (Figure 23), with thin areas in the epidermal walls and near areas where epidermal cells were beginning to slough (Figure 24). Examination of similar materials stained with ruthenium red showed bacteria embedded in a heavy mucigel on the surface of the host cell wall. Fibrillar materials were common in the slime of the root cell wall and the thin bacterial capsule (Figure 25,34a-b). The epidermal layer of matured uninoculated roots appeared as discrete, intact, undulating surfaces, and lacked thinned walls or evidence of sloughing (Figure 26).

Examination of $1,2,3$, and 4 weeks old inoculated roots revealed that infection does not occur at the meristematic region but does occur in older regions of the root. There was progressive sloughing of epidermal cells in older tissues. Bacteria entered spaces between sloughed epidermal layer and cortex (Figure 27) and concurrently, invaded the exposed middle lamellar regions of underlying tissue (Figure 28a-b). Azospirilla also gained entrance through lysed root hairs (Figure 29) and void spaces created by lateral root emergence (Figure 30 ).

Zones of hydrolysis in the middle lamella of invaded tissues were prominent and these zones appear to follow the contour of the bacterial cell wall (Figure 28b).

The plasmalemma drew away from the wall of cells which were in close contact with the bacteria (Figure 24). Loss of cell 
Figure 21. Root cell wall of pearl millet (cw) has staining property as that of the envelope that enclosed the rhizosphere bacteria (B) in Figure 22. $\left(\begin{array}{ll}X & 30,534)\end{array}\right.$

Figure 22. Two or several azospirilla are enclosed in a comion envelope. Note some of the azospirilla that are encilosed as compared with the other bacteria that are free. ( X 16,509)

Both stained with $\mathrm{DAB}$ and were not post stained. 

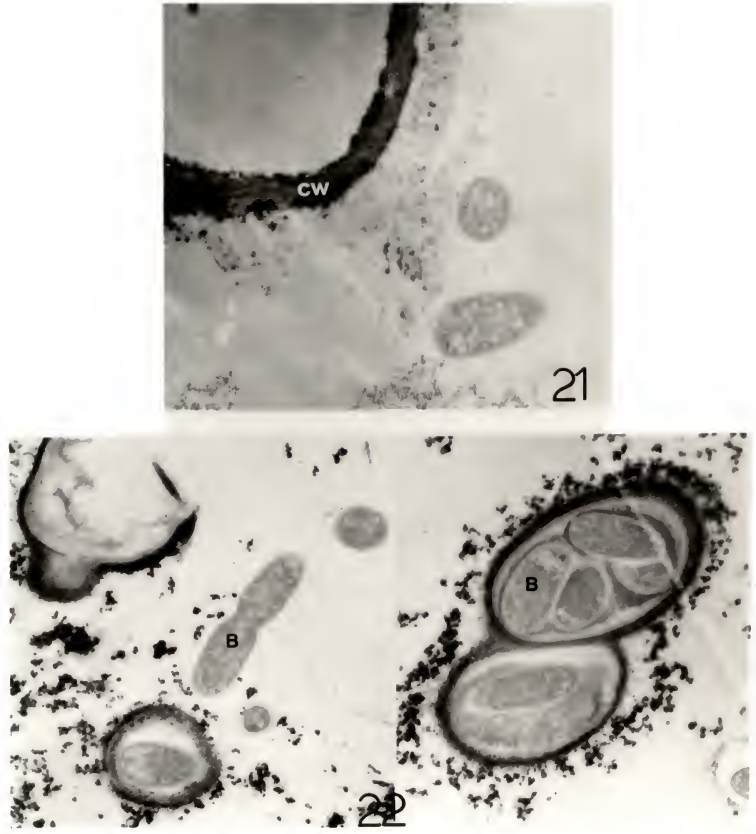
Figure 23. Dark field photomicrograph of pearl millet root showing microcolonies (arrow:! associated with mucigel on the root surface and root hair. RH - root hair; ra - root axis ( $x 141)$

Figure 24. Thinning of epidermal walls (arrows) of guinea grass root associated with microcolonies of A. brasizense Sp 7 . ( X 5,636)

Figure 25. Fibrillar materials are in contact with the bacteria in the surface of the root cell wall (cw) of pearl millet. Note dark granules (arrows) common to the cell wall and the bacteria. ( $x$ 6,272)

Stained with ruthenium red. 

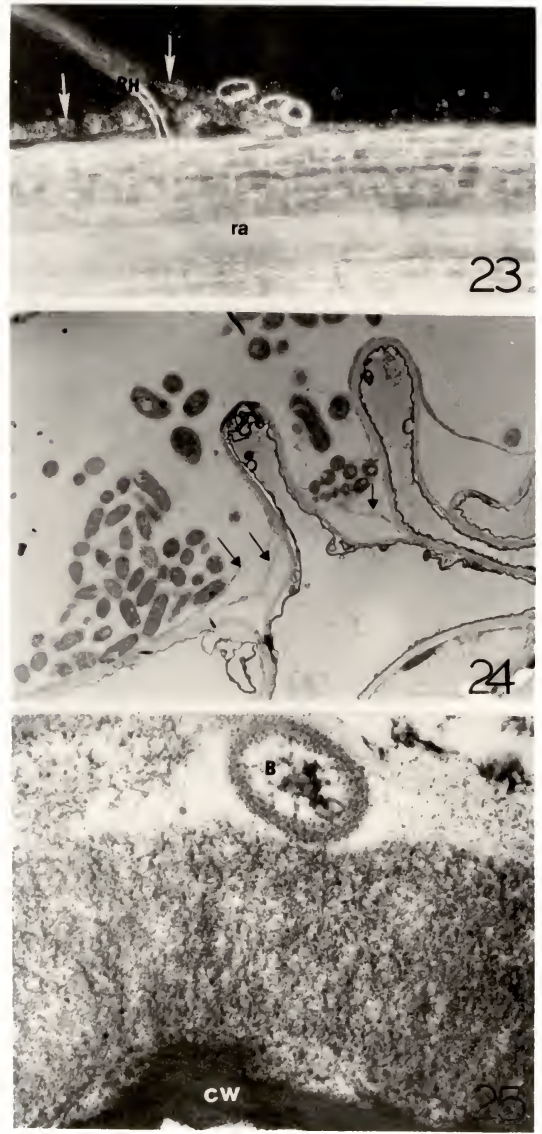
Figure 25. A x-section from a matured root of a 1 month old uninoculated guinea grass. The epidermal layer (arrows) is compact and undulating. $(\times 5,293)$

Figure 27. TEM photomicrograph of a serial thin section of a guinea grass root from above the root hair region. Bacteria enter through void space (arrows) between the sloughed epidermal layer (E) and cortex (C). ( X 3,600) 

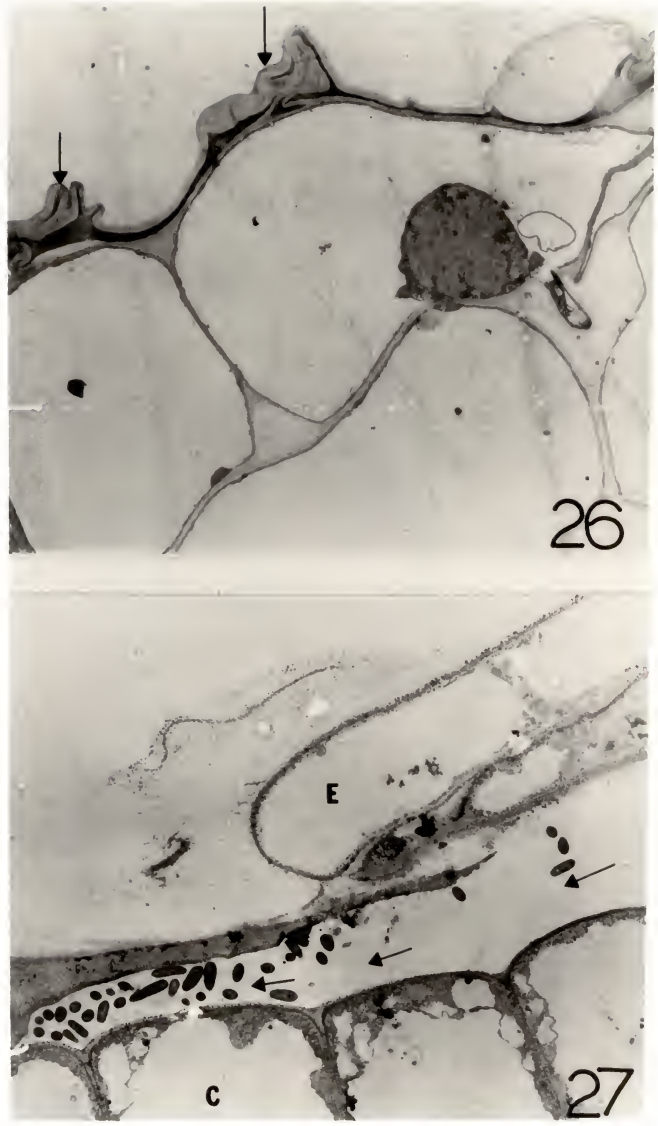
Figure 28a. Serial thin section in which the root is sectioned and the bacteria are shown outside and inside the middle lamella of the cortical cells after the epidermal layer has sloughed. Note the darkly stained cytoplasmic components in the vacuole (V). The specimen was 3 days old following inoculation. ( $\times 6,400)$

Figure 28b. A higher magnification of similar thin section showing the bacteria in the middle lamella of the cortical cells. $v$ indicates vesicles in the middle lamella. ( $x$ 32,941)

The plant host is guinea grass. 

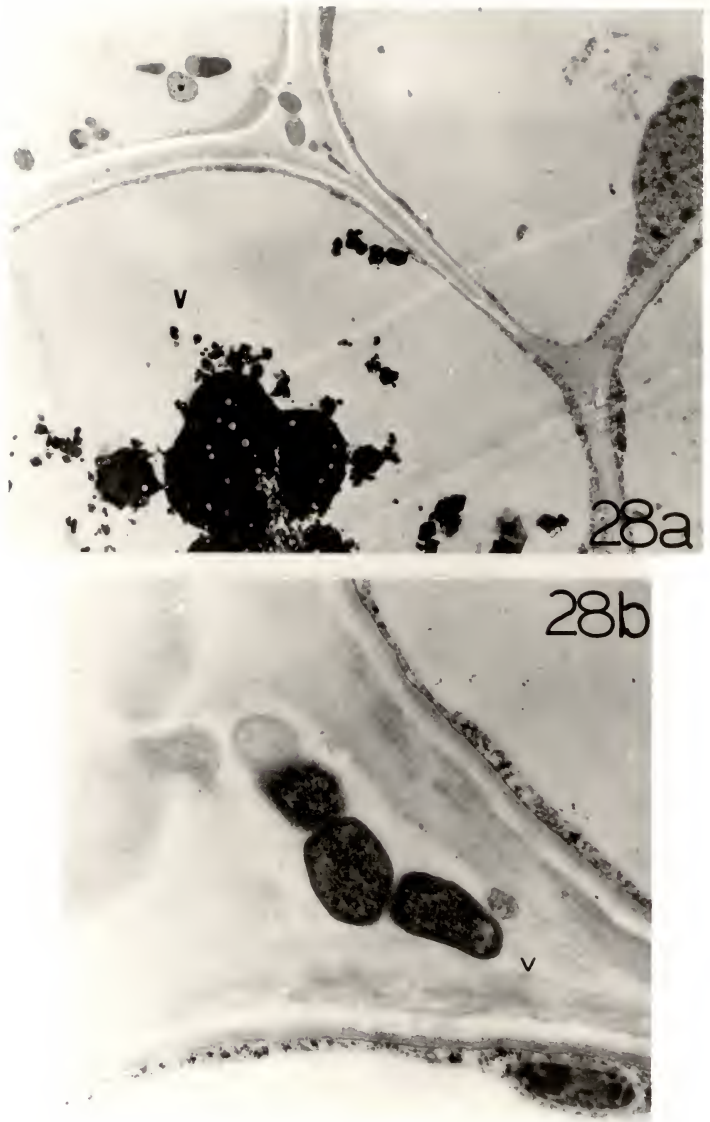
Figure 29. TEM photomicrograph of a lysed root hair of guinea grass showing entry of azospirilla. $(\times 3,381)$

Figure 30. A thin section from a section above the root hair region of guinea grass root showing azospirilla in the void space created by emerging lateral root primordium $(p)$. Vesicles and mitochondria are seen in the cytoplasm of cells adjacent to the infection site. $(x 8,662)$

Figure 31. Serial thin section of guinea grass root showing middle lamella of cortex with invading azospirilla. There is apparent division of one bacterium (B). Note polysomes (arrows) and vesicles $(v) . \quad(X 18,666)$ 

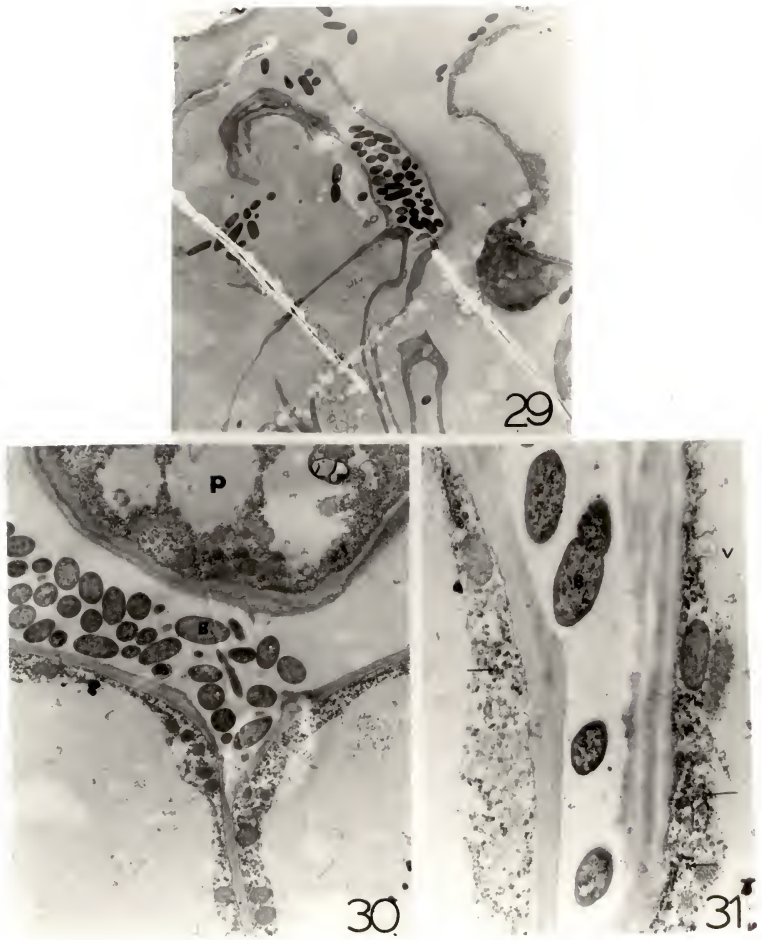
wall integrity (Figure 34a-b), accumulation of degraded cytoplasmic components (Figure 28a), and presence of fibrillar materials near regions colonized by the bacteria (Figure $34 a-b, 25)$, were early manifestations of the host response to the organism. However, after a week, very few cells showed degradation of the cytoplasmic components, although some dark staining bodies could still be seen in the cytoplasm.

Examination of roots from older cultures showed progressive infection of middle lamellae of inner cortical tissues (Figure 32) and apparent division in the middle lamellae of this tissue (Figure 31). The bacteria had very dense cytoplasm and lacked stored PHB but the bacteria were not observed inside the living cells. Fibrillar materials were not observed around the bacterial cells in the middle lamella of the roots from older cultures. The host responses to invasion were shown by vesiculation in the middle lamellae (Fiqure 28a) and in the cytoplasm (Figure 30, 31, 32), and production of conspicuous endoplasmic reticula, polysomes and Golgi apparatus. TEM examination of similar root segments from the uninoculated plants grown in $-N$ medium did not exhibit such characteristics of the cytoplasm. The only instance where $A$. brasizense Sp 7 cells were observed inside the host cells was when the latter were moribund. (Figure $34 a$ ). Some bacteria that were exterior to but in contact with the cell wall of the host had thin capsular coat (Figure 34a-b). The absence of encapsulated bacteria inside the host cells may be due to inability of ruthenium red to penetrate deeper in the tissue of the host. The bacteria that were completely covered with middle lamellar material appeared to have 
Figure 32. Spread of infection of $A$. brasizense Sp 7 in the middle lamella of cortical tissue of guinea grass root. The middle lamella (ML) is eroded. There are numerous polysomes (arrows), mitochondria (m) with compact cristae, and vesicles (v). $(\times 34,285)$ 


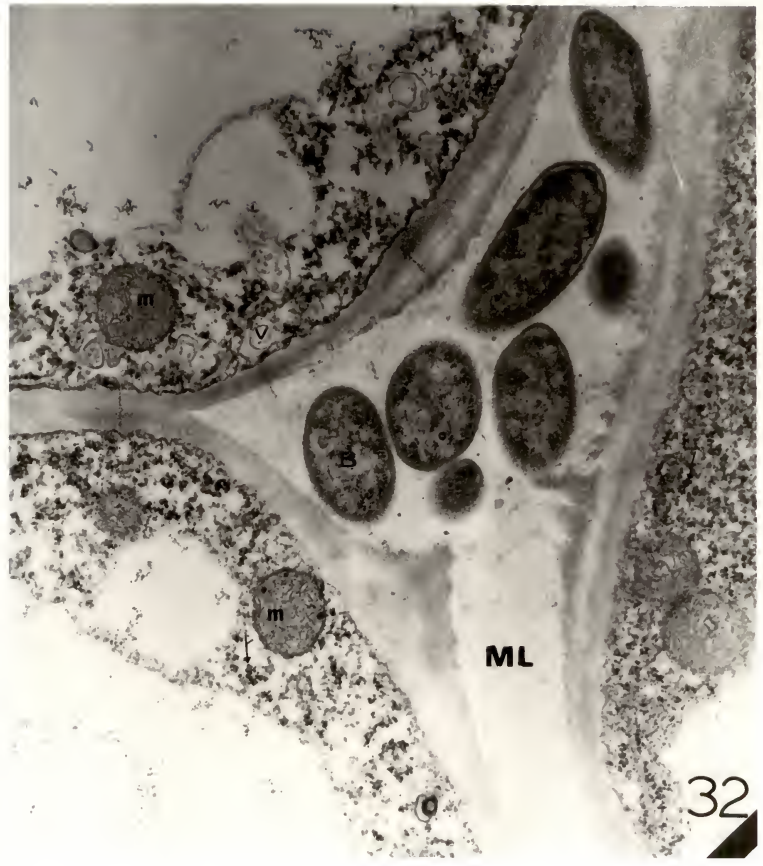


Figure 33a. TEM photomicrograph of cortical cells from similar root segment as in figure 32 from an uninoculated guinea grass grown in nitrogen-free medium $(X 4,694)$

Figure 33b. TEM photomicrograph of cortical cells from simi iar root segment as in Figures 32 and $33 a$ from an uninoculated guinea grass grown in the presence of nitrogen. ( $(x 5,526)$ 

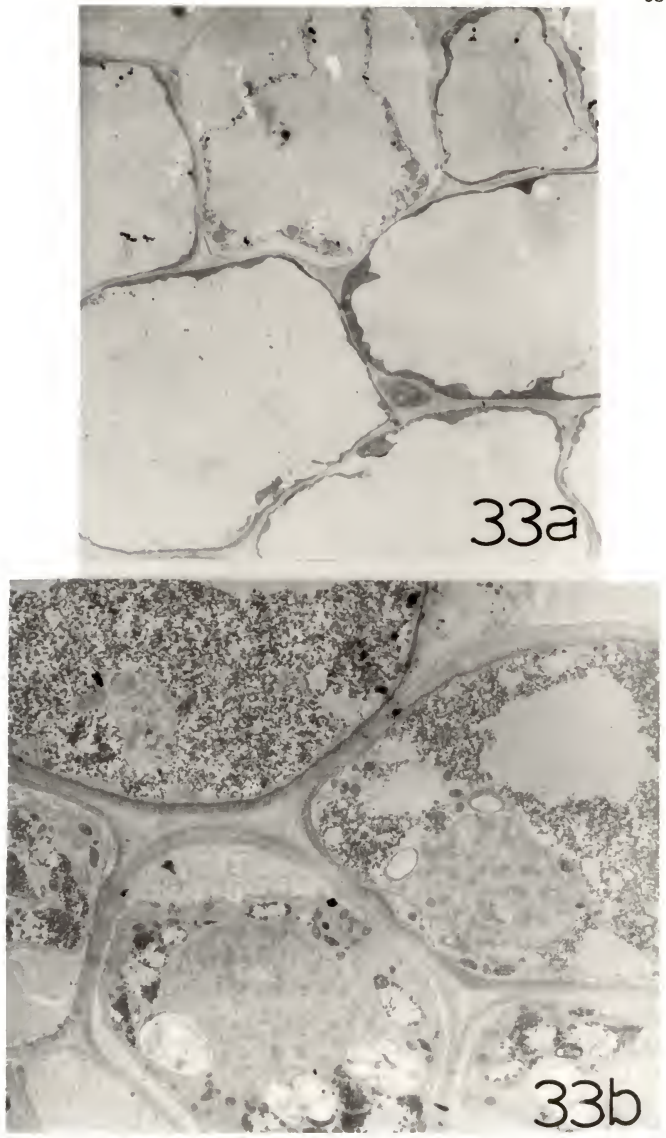
Figure 34a. Azospirilla on and inside pearl millet root cells. The azospirilla (marked area) on the outer region of the host cell wall are encapsulated. The cytoplasm is moribund. (X 14,400)

Figure 34b. A high magnification of the marked area in Figure 34a. The arrows point to the capsule. $(x 85,105)$ 


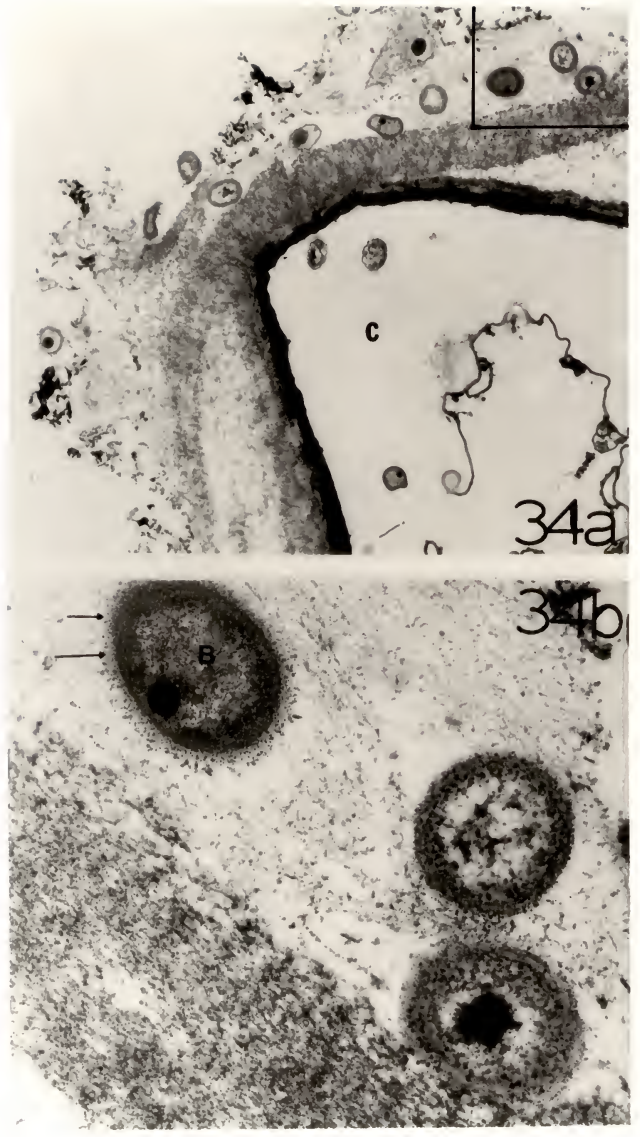


Figure 35. Azospirilla witn thickened walls enveloped with middle lamellar components of pearl millet cortical cell. Stained with ruthenium red. $(x 19,800)$ 

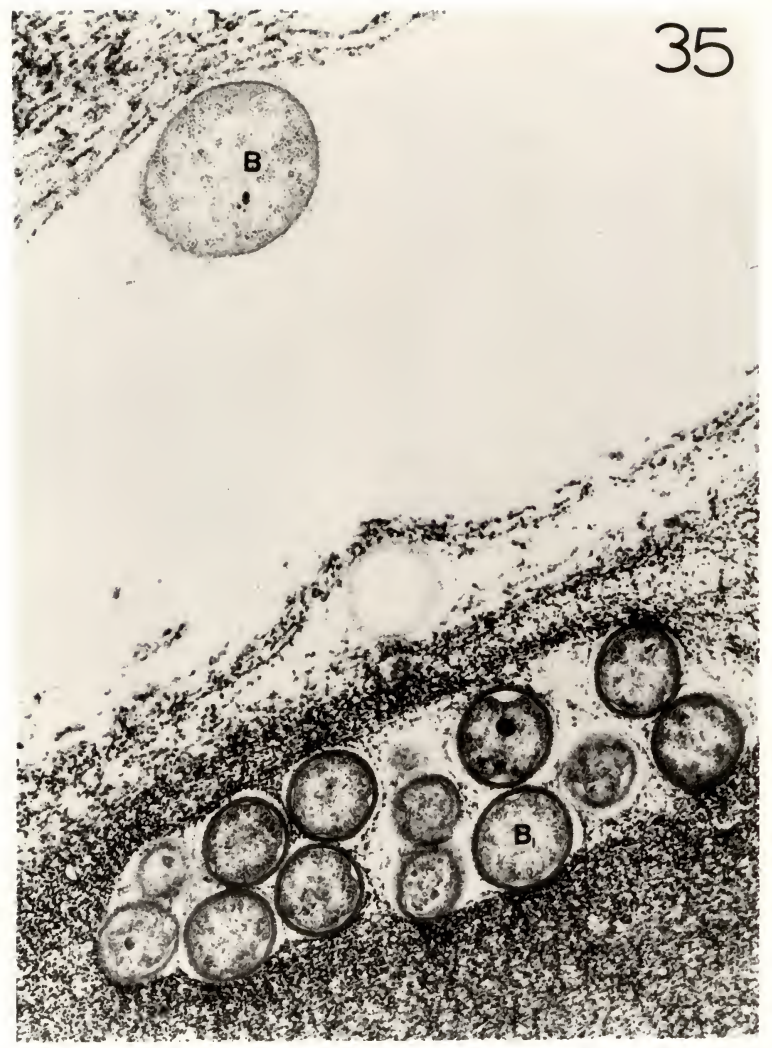
thicker walls than those outside the host cells. A. brasizense Sp 7 was reisolated from similar root materials used in SEII and TEM studies by use of Dobereiner and Day's technique (Dobereiner and Day, 1974).

\section{Pectolytic Enzyme Activity}

The middle lamella consists largely of pectic material (Esau, 1977; Northcote and Pickett-Heaps, 1966; Hall et a1., 1976). Hydrolysis of the middle lamellae of colonized roots suggested digestion of pectin components by the invading bacteria (Guchert et a1., 1975). The hydrolyzed areas observed in the middle lamellae of colonized host cells in this study may be evidence of digestion of pectin components. It was not known whether this was caused by the pectic enzymes of the bacteria or by the induction of enzymes of the host by the presence of the bacteria.

Dobereiner's mineral medium (Dobereiner, 1974) with pectin as carbon source was not highly satisfactory for growth of A. brasilense Sp 7 because the $\mathrm{pH}$ declined as the cells grew, and the lowered $\mathrm{pH}$ suppressed further growth. Growth was better in the mineral medium described by Okon et al. (1977) which contains much higher phosphate levels and thus is more strongly buffered (Figure 1). The importance of a high phosphate level in the media used in pectolytic enzyme assay was emphasized by Hankin et al. (1977).

Variable pectolytic activity was detected on pectin agar plates seeded with live inoculum. Presumptive pectolytic activity was detected as zones of hydrolys is on pectin agar plates surrounding wells which contained $\left(\mathrm{NH}_{4}\right)_{2} \mathrm{SO}_{4}$ precipitated fractions 
from culture filtrates of $A$. brasizense Sp 7 (Figure 36). Activity was not detected if pectin was deleted from the broth culture. The hydrolytic activity exhibited by the fractions in the plate assay suggested that more than one enzyme may be present in the culture filtrate. Zones of hydrolysis also developed around wells containing washings from the pelleted cells grown on pectin broth.

Pectin lyase was detected in very small amount in the different fractions (Figure 37a). Fraction 5 (specific activity of $32.5 \mu \mathrm{g} / \mathrm{ml}$ ) was used in the assay for polygalacturonase activity (Figure 37b). Gel filtration chromatography of polygalacturonic acid digestion products showed that oligosaccharides of various molecular weights were generated from incubation of substrate with this fraction. The degradative activity present in the fractions was destroyed by boiling. 
Figure 36. Clearing of areas around wells on pectin agar plate suggesting a presumptive pectolytic activity of the different fractions obtained from the culture filtrate through $\mathrm{NH}_{4}$ ) $2 \mathrm{SO}_{4}$ precipitation. C - citrate-phosphate buffer; E - commercial enzyme pectinase $(1 \mathrm{mg} / \mathrm{ml})$; numbers $1-5$ are fractions from the culture filtrate: $1-0-20 \%, 2-20-40 \%, 3-40-60 \%$, $4-60-80 \%$, and $\left.5-80-95 \% \mathrm{NH}_{4}\right)_{2} \mathrm{SO}_{4}$ saturation. 


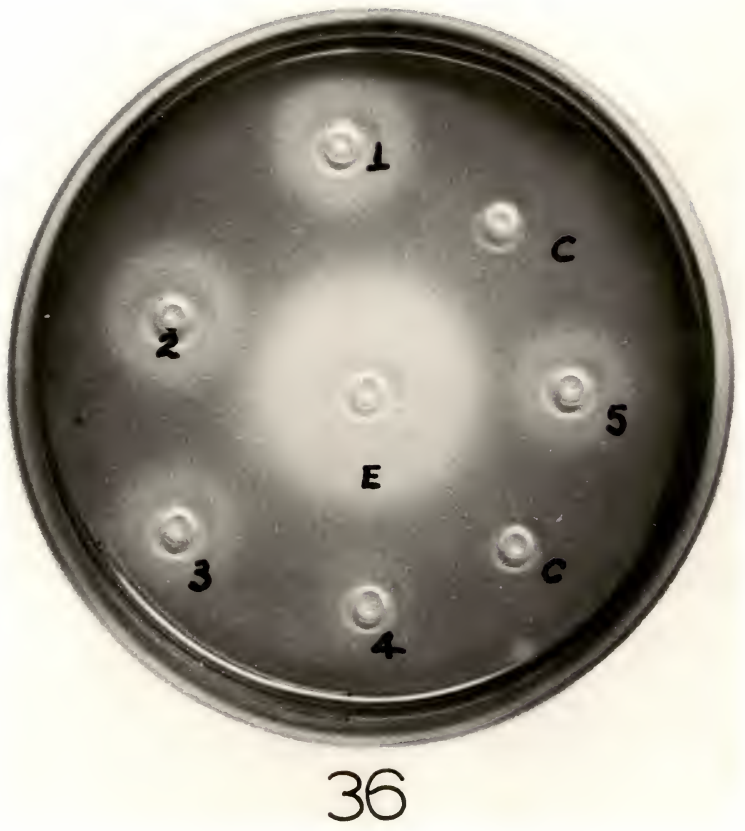


Figure $27 a$. Pectin lyase activity of bacterial washing $\left(B_{3}\right)$ and the fifth fraction $\left(F_{5}\right)$ from the culture filtrate.

Figure 37b. The elution profile of the degradation product of the polygalacturonic acid by $F_{5}$. Dotted line is boiled fraction, solid line is unboiled enzyme fraction. 

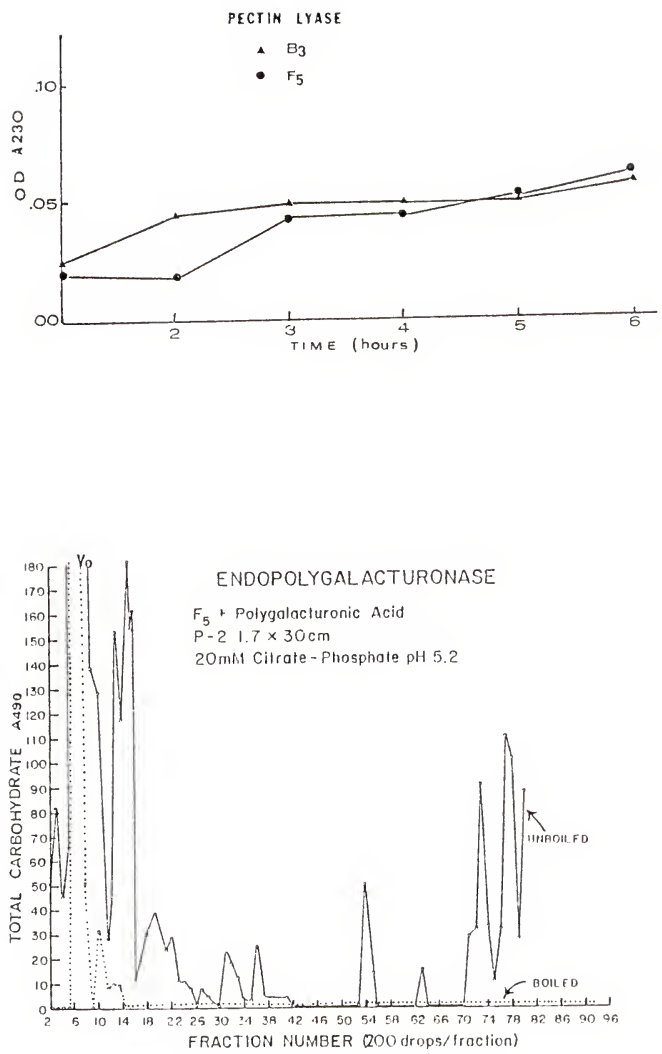


\section{Growth Studies}

A. brasizense sp 7 exhibited a normal growth curve in TSB. The irregular pattern of the growth curve in pectin broth might have been due to the effect of added $\mathrm{NH}_{4} \mathrm{Cl}$, the exhaustion of which may have limited cell division prior to synthesis of nitrogenase. The resumption of growth may be derived from fixed N2.

Negatively stained $48 \mathrm{~h}$ TSB grown cells revealed the bacteria to be coated by a darkly stained polysaccharide. The aggregates of 3 or more cells enclosed in a common coating perhaps constitute the flocs seen under the light microscope.

Azospirilla formed rosettes at $24-48 \mathrm{~h}$ in pectin broth. There were also cells that were aligned end to end similar to the $48 \mathrm{~h}$ old cells in TSB and those reported by Dazzo and Milam (1976). Chain and rosette formation observed in the pectin and TSB grown cells were also typical characteristics of cells grown in the presence of the plant host in Fahraeus assemblies.

Cells grown in TSB had very dense cytoplasm with only very few electron transparent bodies (PHB). Cells grown in $-\mathrm{N}$ malate had numerous PHB and polyphosphate bodies. Okon et al. (1976b) found that levels of PHB and $\beta$-hydroxybutyrate dehydrogenase in Azospirizzum were elevated in cells grown in $\mathrm{N}_{2}$ compared with ammonium grown cells. The occurrence of PHB in 
Azotobacter vinelandii grown in $-N$ medium had been reported by Page and Sadoff (1975). Pectin grown cells stored PHB and had prominent polyphosphate bodies, usually at the center of the cell. The prominence of polyphosphate granules stored by pectin grown cells might be caused by high rates of phosphate assimilation. The dense cytoplasm of cells in pectin broth was similar to that in cells observed in the middle lanellae of host root cells.

\section{Host-Bacterium Interaction}

The inoculated solution in the Fahraeus assembly became turbid and remained so until the end of the experiment. The turbidity of the solution indicated the ability of the bacteria to survive and grow in the grass rhizosphere. The young roots of inoculated plants appeared slimy and produced root hairs profusely. Light microscopic examination of $24 \mathrm{~h}$ inoculated roots revealed bacteria attached on various parts of the root system. Two weeks after inoculation the lateral roots were shorter and larger in diameter in inoculated cultures than in uninoculated controls. Forked or whorl type branching of inoculated roots were common. The roots of all the inoculated plants were well developed and the shoots remained green comparable to those grown in $+N$ controls except for purple coloration at the base of the leaf sheaths. The appearance of purple color on the leaves was characteristic of nitrogen deficient sorghum plants as described by Doak and Miller (1968). The fact that $-N$ inoculated plants were comparatively as green as the $+N$ controls suggested that the bacteria were able 
to fix nitrogen but this was not sufficient to maintain the growth of host plants for a long period of time. Carbon dioxide and insufficient mineral supply may have provided limitations for the growth of both plants and microorganisms.

Gaskins et a1. (1977) and Tien et al. (1978) found detectable amount of IAA, gibberellin and cytokinin-like substance from the pure culture supernatant. Carbon compounds such as sugars and amino acids are exuded from the roots of plants (P.ovira, 1969) and are utilized by the organisms. Plants can take up indoles, and auxin can initiate a lateral root stimulation (Scott et al., 1972). Since auxin, cytokinin and gibberellins are synthesized by Azospirizzum in pure culture (Gaskins et 1a., 1977; Tien et a1., 1978), there is a possibility that these substances are also synthesized in the grass rhizosphere. The formation of short branched roots by grasses treated with high levels of Azospirizlum inoculum is typical of the hormone effect described by Slankis (1973) in ectomycorrhizal roots. The production of more lateral roots and more persistent and profuse root hairs by inoculated plants is evidence of stimulation by auxin as described by Scott et a1. (1977). The interaction of hormones produced by Azospimizlum has not been thoroughly studied although characteristic root morphogenes is has been induced in axenic culture using different combinations of hormones (Tien et a1., 1979). Both the hormone effect and the fixation ability of Azospirizzum will require further investigation before the beneficial effects of inoculation can be understood. However, the increased dry weight of inoculated plants over the 
uninoculated controls and the turbidity of the solution throughout the duration of the experiment suggests that both plant and bacteria benefited from the association.

Roots of the inoculated plants produced more mucigel and formed more lateral branches and more root hairs than those of uninoculated controls. The phenomenon of enhanced mucigel production by roots when in association with the bacteria has been reported in a legume (Dart and Mercer, 1964), in wheat (Rovira and Campbe11, 1974), and in several plant species grown in field and garden soil (Greaves and Darbyshire, 1972). Examination of inoculated roots showed mucigel to be most abundant at the root tip, especially at the root cap and the maturation region and root hairs. Matured undifferentiated epidermal cells have some amount of mucigel but surfaces of older tissues are devoid of it. Cortical cells adjacent to the infected sites appeared to have more numerous Golgi bodies, rough endoplasmic reticula and vesicles indicating high biosynthetic activity. Similar tissues from the uninoculated roots appeared to have few of these organelles. The apparent presence of more organelles in inoculated roots may be due to the fixed nitrogen by the bacteria. The Golgi apparatus-mediated secretion of polysaccharide by outer root cap cells of Zea mays has been well documented by the studies of Morre' and Mollenhauer (1967), Juniper and Roberts(1966) and Northcote and Pickett-Heaps (1966). The relative contribution of plant and bacteria to mucigel production in inoculated plant cultures is not known. Nevertheless, the possibility of complementary slime production by both bacteria and host should not 
be overlooked since slimy material settles at the bottom of the flask when the bacteria were grown in pure culture and this material stained positively with polysaccharide stains, phosphotungstic acid and ruthenium red. It would seem worthwile to follow the production of mucigel or exudation of carbon compounds such as sugars and amino acids with labelled compounds fed to the leaves of the host plant.

The presence of numerous clumps of bacteria in the mucigel may be significant to the economy of the grass-bacteria association. The mucigel may mediate ion exchange between the immediate soil environment and the root surface of the plant or the microorganism (Greaves and Darbyshire, 1972; Jenny and Grossenbacher, 1963). The mucigel seems to provide a protective niche for rapid bacterial multiplication, perhaps by accumulating root exudate or by preventing subsequent colonization by other organisms. The mucigel may promote nitrogen fixation by protecting the enzyme nitrogenase by limiting $\mathrm{O}_{2}$ diffusion.

Bacteria outside the host cells and in close contact with the plant cell walls and/or mucigel showed irregular cell coat indicating differential synthesis or breakdown of extracellular material. Fibrillar materials and small electron dense granules on the area where the bacteria and host cell wall were associated might be a part of a recognition or binding site. The electron dense granules may be aggregation of proteins since these granules were not seen when the material was not post stained with lead citrate or uranyl acetate. The fibrillar structure have been reported in the Rhizobium-legume (Napoli et al., 1976) and in 
broad bean-saprophytic bacterium interaction (Sing and Schroth, 1977). The absence of fibrillar material around the bacterial cells when the bacteria were in the middle lamella or inside the host cells and their ability to divide in the middle lamella has a resemblance to the Rhizobium-clover system in the sense that the bacteroids do not have the characteristic fibrillar structure present around the infecting rhizobia. The absence of this material around the azospirilla seen in the middle lamella of the grass host mav also be due to the poor penetration of ruthenium red. However, the fibrillar structure shown in Napoli's photomicrograph of the infecting rhizobia (Napoli et al., 1975) were demonstrated in materials that were not stained with ruthenium red. It is expected that if, similar structures were present around cells inside the middle lamella of the arass host, could also be demonstrated with post stainina with lead citrate and uranyl acetate。 Mucigel is produced by plants arown in the $+\mathrm{N}$ and $-\mathrm{N}$ culture. However, bacteria were adsorbed to the mucigel at the root cap and epidermis in root grown in $+\mathrm{N}$ but not to the root hairs. The mechanism of control is not yet understood. The same phenomenon of reduced adherence of $R$. trifoli $i$ to clover root hairs grown in $+\mathrm{N}$ was also reported by Dazzo and Brill (1978) in the Rhizobium-clover symbiosis. Reduction in selective adherence of rhizobia to clover root hairs was concurrent with the decrease in the immunologically detectable levels of the recognition lectin, trifoliin.

The roots of grasses used in the adsorption studies displayed selectivity in their binding of bacteria to certain 
regions of the root. Cells were firmly adsorbed to root hairs of plants grown in the absence of nitrogen. However, bacteria were associated only with the mucigel at the root cap and epidermis above the root hair region in roots grown in the presence of nitrogen and were not adsorbed to root hairs. The root hairs also displayed selectivity in their binding of certain kinds fo bacteria. It is interesting to note that $R$. trifoli $i$ and $P$. fluorescens adhered to pearl millet roots since these bacteria share certain immunological (Dazzo and Milam, 1976) and biochemical (Tarrand et a1., 1977) characteristics with Azospirizzum. The mechanism of adherence, and hence the reason for these differences in bindina is unknown.

TEM studies revealed random microcolonies on areas where mucigel was present and where root cell walls were thin. There was invasion of the middle lamella in areas where the mucigel was slight or absent and where the epidermis was sloughed. Bacterial colonization of epidermal cells that had no mucigel was noted by $01 d$ and Nicholson (1975) in field grown sand dune grasses. The thinning of cell walls associated with microcolonies suggests hydrolytic enzyme in those areas. Absence of mucigel on surfaces where there was invasion of epidermal tissues and underlying cortical tissues could be explained as follows: The plant tissues in those regions may already be very old, and therefore have lost the capacicy to produce slime. It is also possible that the mucigel in those areas may have been degraded by the organisms, as suggested by the transparent zones surrounding the cells in the middle lamella and the mucigel layer that follow the contour of the bacteria. In field grown sand dune grasses the bacteria were inside the root tissues in areas where the mucigel was not present (01d and Nicholson, 1975). The invasion of 
older parts of the root and not the very young tissues (e. g. meristematic tissue) at the root tip seems reasonable for the microorganisms if exudation sites are considered. Studies using ${ }^{14} \mathrm{C}$ labelled assimilate have shown that diffusable exudate is released along the full length of the root while non-diffusable carbon compounds come from the root tip region (Rovira, 1969). The production of soluble exudates in the root cortex and the outward diffusion through intercellular spaces would make the niches between the epidermal cells (Tinker and Sanders, 1975) and middle lamellae of the cortical tissues favorable nutritionally for bacterial growth. Analys is of the composition of the mucigel of maize has been reported by Northcote and Pickett-Heaps (1966) and of wheat by Dayan et a1. (1977). In maize, fucose was the only sugar not present in the mucigel of plants studied. Labelling this particular sugar paved the way to a better understanding of the synthesis of polysaccharide in the roots of maize. An understanding of the effect of root exudate composition may help understand the apparent specificity of infection of grasses by Azospirizlrm. Sugars and amino acids in the root exudate may offer a selective advantage for certain microorganisms.

As seen in the TEll micrographs, the staining reaction to ruthenium red by mucigel on the outer cell wall of the plant cell and by those of the interlamellar materials suggests that pectic components were common to both parts of the host cel1. The presence of transparent areas in the mucigel and in the middle lamellae where the bacteria are present suggest hydrolysis of the component material. The presence of numerous bacteria in the mucigel 
mucigel suggests that this substance may be of considerable influence on the rhizoplane population (Brams, 1969).

Age of inoculum affected the rapidity with which azospirilla adhered to the root hair surface only under the short term incubation ( e.g. 1 h -12 h). Forty eight hour old cultures adsorbed more to the root hairs than did the $12 \mathrm{~h}$ old cultures. Napoli (pers. comm.) observed that $48 \mathrm{~h}$ cultures of rhizobia vere more infective than younger cultures. Similar trends in attachment studies of $R$. trifolii 0403 to clover root hairs has been demonstrated by Dazzo et al. (1976). The phenomenon was believed to be a result of transient adherence of polysaccharide on the Rhirobium cell surface. Detected polysaccharide has been shown to undergo immunological changes as the cells enter stationary phase. These chemical changes were considered to reflect increased adherence of rhizobia to the root hair surface.

The entry of bacteria through lysed root hairs and void spaces created by sloughed epithelial cells and branching roots has been reported by Umali-Garcia et al. (1978). The bacteria remained intercellular in plant root tissue, but could enter the root cells when the cytoplasm became moribund. Bacteria were not seen in the xylem of roots grown undisturbed in Fahraeus assemblies, but were seen in xylem of roots that were severed or injured and dipoed in inoculum for 5 minutes. Other workers, (Lakshmi et al., 1977; Patriquin et al., 1978) have reported Azospirizlum in the xylem vessels of maize and sugar cane roots grown in solid medium (e. g. sand-soil mixture). The invasion of xylem vessels of grass 
roots may be a consequence of mechanical injury, since the observations were made on roots grown in and removed from solid medium prior to inoculation. Invasion of inner tissues of the roots is very likely to occur in the field as has been described by $01 \mathrm{~d}$ and Nicholson (1975) and Foster and Rovira (1973).

The host cells near infected areas underwent cytoplasmic changes. The appearance of numerous endoplasmic reticula, free ribosomes, mitochondria with compact cristae, increase in the number of dictyosomes and accumulation of vesicles close to the cell wall after 1 month interaction of the bacteria and host plant suggest rapid biosynthetic activity and rapid turnover of synthesized materials. Dictyosomes are thought to be involved in formation of the cel1 wal1 (McCoy, 1932; Mollenhauer and Morre', 1966; Northcote and Pickett-Heaps, 1966). The formation of vesicles may have arisen from the demand for increased cell wal1 formation due to infection (Tu, 1976).

Pectin lyase and endopolygalacturonase have been detected in cultures of $A$. brasilense Sp 7. Pectolytic enzyme involvement in plant infection by pathogenic microorganisms has been well documented (Basham and Bateman, 1975; Bateman and Millar, 1966; Fisher et a1., 1973; Albersheim et a1., 1969; Mussell and Strand, 1976). The presence of these pectin hydrolyzing enzymes may explain the loosening of microfibrils of the host cell wall and consequent decrease in stainability of areas associated witi azospirilla. U1trastructural evidence for digestion of mucigel by bacteria was reported by Guchert et a1. (1975). The effect of pectic enzymes 
on solubilization of proteins bound to plant cell walls has been reported by Lund and Mapson (1971), Steohen and Wood (1974), and Strand and Musse11 (1975). Peroxidase activity was reported to be associated with the proteins released from cell walls by polygalacturonase (Strand et al., 1976). The thick and predominantly dark root cell wall of inoculated plants reacted with 3 , 3-diaminobenzidine $(D A B)$, a substance for peroxidase, suggest peroxidase activity (Umali-Garcia et a1., 1976, Unpub.). The presence of peroxidase on the walls of inoculated plants may be an effect of the enzyme released by endopolygalacturonase produced by the bacteria.

Thinning of epidermal cell walls associated with azospirilla suggests that pectolytic enzymes produced by the bacteria are active in the early invasion process. If related to infection and subsequent invasion, a rapid increase in enzymatic activity during the early phase of infection would be expected. The demonstration of this activity in the solution of plant culures would be worth attempting. Identifying of the different enzyme species involved and determining which type predominates at specific phases of the infection process would contribute to the understanding of the establishment of the association.

Light microscopic examination of older cells of Cynodon dactyzon isolates by Eskew et a1. (1977) were reported to produce cell clusters which he interpreted as "cyst-like" in $-N$ medium when the bacteria were in the stationary phase. Zoogloeia-like clusters of cells were also formed by Beijerinckia fluminensis (Dobereiner and Ruschel, 1958). Dobereiner (1974) believed that these might 
have a role in protecting the cells from oxygen. Negatively stained azospirilla in stationary phase revealed 3 or more cells sharing a common slime coat. It should be interesting to follow up the occurrence of these structures in different culture media to relate their role to survival of azospirilla in the field and laboratory. Azotobacter has been shown to produce cyst in old cultures, and the cyst were related to better survival in the field (Brown et al., 1964).

Most field inoculation with azospirilla used suspension of washed bacteria in the late exponential phase. 01d inoculum showing low metabolic activity has not been used. The use of 11 day old culture has been tried in glass assemblies and showed promise of good survival (Umali-Garcia et al., 1976, Unpub.). The role of the age of inoculum on survival of azospirilla in the field needs consideration.

Perforations on the walls of exposed cell lamellae as reported by $01 \mathrm{~d}$ and Nicholson (1975) were not observed in this study. Distorted and collapsed epidermal cells extensively colonized by bacteria as described by Foster and Rovira (1973), were obvious in root tissues examined. Perforations in field grown plant roots may result from the presence of vesicular-arbuscular endophyte that $01 \mathrm{~d}$ and Nicholson (1975) have noted. It may also result from entry of other soil organisms such as nematodes. These perforations were not seen in the scanning electron micrographs of inoculated pearl millet grown in axenic cultures.

The presence of azospirilla in the middle lamella of the cortical tissues and in the mucigel suggests an intimate association. The presence of active cytoplasm of the host and existence of divid- 
dividing cells in the host tissues further suggests compatibility of the association.

The experiments reported here show that Azospirizlum brasilense under axenic conditions is invasive on grass roots and that there is intimate but limited colonization of the middle lamella within the root cortex of the young roots. Limited internal colonization of the root is confined to the middle lamellar region, and may limit the agronomic exploitation of this $\mathrm{N}_{2}$-fixing association. 


\section{LITERATURE CITED}

Abrantes, G. T. V., J. M. Day and J. Dobereiner. 1975. Methods for the study of nitrogenase activity in field grasses. Bul. Int. Biol. Lyon 21.

Albersheim, P. 1966. Pectin lyase in fungi. In: Colowick, S. P. and N. 0. Kaplan (eds.). Methods in Enzymology 8: 628-631. Academic Press, Inc. New York.

Albersheim, P., T. M.Jones and P. D. English. 1969. Biochemistry of the cell wall in relation to infective processes. Ann. Rev. Phytopath. 7: 171-194.

Balandreau, J. P., C. R. Millier and Y. R. Dommergues. 1974. Diurnal variations of nitrogenase activity in the field. Appl. Microbiol. 27: 662-665.

Balandreau, J., G. Rinaudo, I. Fares-Hamad and Y. Dommergues. 1975. Nitrogen fixation in the rhizosphere of rice plants. In: Stewart, W. D. P. (ed.). Nitrogen Fixation by Freeliving Microorganisms. Cambridge University Press. New York. pp. 57-70.

Balandreau, J. P. and G. Villemin. 1973. Fixation biologique del'azote moleculaire en savane de Lamto (Basse Cote D'Ivoire). Resultas preliminaires. Rev. Ecol. Biol. Sol. 10: 25-33.

Barber, L. E. and H. J. Evans. 1976. Characterization of a $\mathrm{N}_{2}$-fixing strain from the roots of Digitaria sanguinalis. Can. J. Microbiol. 22: 254-260.

Barber, L. E., J. D. Tjepkema, S. A. Russell and H. J. Evans. 1976. Acetylene reduction ( $\mathrm{N}_{2}$-fixation) associated with corn inoculated. with Spirizlum. Appl. Environ. Microbiol. 32: 108-113.

Barea, J. M. and M. E. Brown. 1974. Effects on plant growth produced by Azotobacter paspali related to synthes is of plant growth regulating substances. J. Appl. Bacteriol. 37: 583-593.

Barnett, N. M. 1974. Release of peroxidase from soybean hypocotyl cell walls by Scletorium rolfsii culture filtrates. Can. j. Bot. 52: 265-271. 
Basham, H. G. and D. F. Baterian. 1975. Killing of plant cells by pectic enzymes: The lack of direct injurious interactions between pectic enzymes or their soluble products and plant cel1s. Phytopath. 65: 141-153.

Bateman, D. F. and R. L. Millar. 1966. Pectic enzymes in tissue degradation. Ann. Rev. Phytopath. 4: 119-145.

Becking, J. H. 1963. Fixation of molecular nitrogen by an aerobic Vibrio or Spirizlum sp. Antonie van Leewnhoek J. Microbiol. Serol. 29: 326.

Becking, J. H. 1975. Root nodules in nonlegume. In: J. G. Torrey and D. L. Clarkson (eds.). The Development and Functions of Roots. Acad. Press. London. pp. 507-566.

Beijerinck, M. W. 1925. Uber ein Spirizzum welches freinen stickstoff binden kann? Zentralbl. Backteriol. Parasitendk. Infektionskr. Hyg. Abt. 263: 353-359.

Bergersen, J. 1970. The quantitative relationship between nitrogen fixation and the acetylene reduction assay. Aust. J. Biol. Sci. 23: 1015-1025.

Bergey's Manual of Determinative Bacteriology. 1957. 7th ed. Williams and Wilkins Co. Baltimore, Maryland.

Bouton, J. H. 1977. Response of pearl millet inbreds and hybreds to inoculation with Spirizlum lipoferm. Doctoral dissertation. University of Florida, Gainesville. August, 1977.

Bowen, G. D. and A. D. Rovira. 1976. Microbial colonization of plant roots. Ann. Rev. Phytopath. 14: 121-14..

Brams, E. 1969. The mucilaginous layer of citrus roots: Its dileneation in the rhizosphere and removal from roots. Plant Soil 30: 105-108.

Brown, M. E. 1972. Plant growth substances produced by microorganisms of soil and rhizosphere. J. Appl. Bacteriol. 35: $443-451$.

Brown, :1. E. 1976. Role of Azotobacter paspali in association with Paspalum notatum. J. Appl. Bacteriol. 40: 341348 .

Brown, M. E., S. K. Burlingham and R. H. Jackson. 1964. Studies on Azotobacter species in soil. III. Effect of artificial inoculation on crop yields. Plant Soil 20: $194-214$. 
Bulow, J. von and J. Dobereiner. 1975. Potential for nitrogen fixation in maize genotypes in Brazil. Proc. Nat. Acad. Sci. 72: 2389-2393.

Burris, R. H. 1976. Non-leguminous $\mathrm{N}_{2}$-fixing system. A synthesis paper. II. Intl. Symp. on Nitrogen Fixation. Salamanca, Spain, 1976.

Campbe11, R. and A. D. Povira. 1973. The study of the rhizosphere by scanning electron microscopy. Soil Biol. Biochem. 5: 747-752.

Carlson, R., C. Napoli and P. Albersheim. 1977. Chemical and immunological studies of the lipopolysaccharide of Rhizobium. Proc. Sixth Am. Rhizobium Conference. August 29 - September 2, 1977. Gainesville, Florida.

Chollet, R. and W. L. Ogren. 1975. Regulation of photorespiration in $C_{3}$ and $C_{4}$ species. The Bot. Rev. 41: 137-179.

Cooke, R. D. , C. E. M. Ferber and L. Kanagasabapathy. 1976. Purification and characterization of polygalacturonase from a commercial Aspergizzus niger preparation. Biochem. Biophys. Acta. 452: 440-451.

Dart, P. J. and F. V. Mercer. 1964. The legume rhizosphere. Archiv. Mickrobio1. 47: 344-378.

Day, J. M., M. C. P. Neves and J. Dobereiner. 1975. Nitrogenase activity on the roots of tropical forage arass. Soil Biol. Biochem. 7: 107-112.

Dayan, E., A. Banin and Y. Henis. 1977. Studies on the mucilaginous layer of barley (Hordeum vulgare) roots. Plant Soil 47: $171-192$.

Dazzo, F. B. and W. J. Brill. 1978. Regulation of fixed nitrogen of host-symbiont recognition in the Rhizobizm-clover symbiosis. Plant Physiol. 62: 18-20.

Dazzo, F. B.and J. R. Milam. 1976. Serological studies of Spirizium iipoferum. Soil Crop Sci. Soc. Florida 35: $122-126$.

Dazzo, F. B., C. Napoli and D. H. Hubbell. 1976. Adsorption of bacteria to root as related to host specificity in the Rhizobium-clover symbiosis. Appl. Environ. Microbiol. 32: $166-171$.

De-Polli, H., E. Matsui, J. Dobereiner and E. Salati, 1977. Confirmation of nitrogen fixation in two tropical grasses by 15N. incorporation. Soil Biol. Biochem. 119-123. 
Dingle, J., W. W. Reid and G. L. Solomon. 1953. The enzymatic degradation of pectin and other polysaccharides. II. Application of the "cup plate" assay to the estimation of enzyme. J. Sci. Food Agric. 3-4: 149-155.

Doak, K. D. and P. R. Miller. 1968. Influence of mineral nutrition on pigmentation in sorhum. Agron. J. 60: 430-432.

Dobereiner, J. 1968. Ilon-symbiotic nitrogen fixation in tropical soils. Perg. Agropic. Bras. 3: 1-6.

Dobereiner, J. 1974. Nitrogen-fixing bacteria in the rhizosphere. In: Quispel, A. (ed.). The Biology of Nitrogen Fixation. North Holland Pub. Co. Amsterdam. pp. 86-120.

Dobereiner, J. 1978. Influence of environmental factors in the occurrence of Spirizzum Zipoferum in the soil and roots. In: Granhall, U. (ed.). Environmental Role of Nitrogenfixing Blue-green Algae and Symbiotic Bacteria. Ecol. Bul1. IFR (Stockholn) 26: 343-351.

Dobereiner, J. and J. M. Day. 1974. Associative symbiosis in tropical grasses: Characterization of microorganisms and dinitrogen fixing sites. Intl. Symp. on $\mathrm{N}_{2} \mathrm{Fixation}$. Interdisciplinary Discussions. June, 1974. Vashington.

Dobereiner, J. and J. M. Day. 1975. Nitrogen fixation in the rhizosphere of tropical grasses. In: Stewart, W. D. (ed.). Nitrogen Fixation by Free-living Microorganisms. Cambridge University Press. Cambridge.

Dobereiner, J., J. M. Day and P. J. Dart. 1972a. Nitrogenase activity of Paspalum notatum-Azotobacter paspali association. J. Gen. Microbiol. 71: 103-116.

Dobereiner, J., J. M. Day and P. J. Dart. 1972b. Nitrogenase activity in the rhizosphere of sugar cane and some other tropical grasses. Plant Soil 37: 191-196.

Dobereiner, J., M. Nery and I. E. Marriel. 1976. Ecological distribution of Spirizzum Zipofemon Beijerinck. Can. J. Microbiol. 22: 1464-1473.

Eira, P. A. de. 1977. Nitrogen transformation in soils under Digitaria decumbens vegetation. Int1. Symp. on the Limitations and Potentials of Biological llitrogen Fixation in the Tropics. Universidad de Brasilia, Brazil, 1977.

Esau, K. 1977. Anatony of Seed Plants. J. Wiley and Sons. N. Y. $376 \mathrm{pp}$. 
Eskew, D. L., D. D. Focht and I. P. Ting. 1977. Nitrogen fixation, denitrification and pleomorphic growth in a highly pigmented Spirillum Zipoferum. Appl. Environ. llicrobiol. 34: 582-585.

Evans, H. J. and L. E. Barber. 1977. Biological nitrogen fixation for food and fiber production. Science 197: 332-339.

Fahraeus, G. 1957. The infection of clover root hairs by nodule bacteria studied by a simple glass slide technique. J. Gen. Microbio1. 16: 374-381.

Fisher, M. L., A. J. Anderson and P. Albershein. 1973. Hostpathogen interaction. VI. A simple plant protein efficiently inhibits endopolygalacturonase secreted by Colletotrichum Zindemuthianum and Aspergizlus niger. Plant Physiol. 51: 489-491.

Foster, R. C. and A. D. Rovira. 1973. The rhizosphere of wheat studied by electron microscopy of ultrathin sections. Bu11. Ecol. MFR (Stockholn) 17: 83-102.

Foster, R. C. and A. D. Rovira. 1976. U1 trastructure of wheat rhizosphere. Hew Phytol. 76: 343-352.

Fred, E. B., I. Baldwin and E. IIcCoy. 1932. The Root Nodule Bacteria and Leguminous Plants. University of Wisconsin Press. lladison. $342 \mathrm{pp}$.

Gaskins, M. H. and J. L. Carter. 1976. Nitrogenase activity: A review and evaluation of assay methods. Soil Crop Sci. Soc. Florida 35: 10-15.

Gaskins, M. H., H. U. Garcia, T. M. Tien and D. H. Hubbe11. 1977. Nitrogen fixation and growth substance production by Spirizlum lipofernm, and their effects on plant growth. Plant Physio1. Supp. 59: 128.

Graham, P. H. and J. Halliday. 1977. Inoculation and nitrogen fixation in the genus Phaseolus. In: Vincent, J. II. (ed.). Exploring the Legume-Rhizobium Symliosis in Tropical Agriculture. Symp. Proc. University of Hawaii Press.

Greaves, M. P. and J. F. Darbyshire. 1972. The ultrastructure of the mucilaginous layer of plant roots. Soil Biol. Biochern. 4 : 443-449.

Guchert, A., H. Breisch and 0. Reisinger. 1975. Interface solracine. I. Etude au microscope electronique mucige 1argile microorganismes. Soil Biol. Biochem. 7: 241. 
Hall, J. L., T. J. Flowers and R. I1. Roberts. 1976. Plant Ce11 Structure and Metabolism. Longman. N. Y. $426 \mathrm{pp}$.

Hankin, L., M. Zucker and D. C. Sands. 1971. Improved soil medium for the detection and enumeration of pectolytic bacteria. Appl. Microbiol. 2: 205-209.

Hardy, R. W. F. and U. D. Havelka. 1976. Photosynthate as a major factor limiting nitrogen fixation by field grown legunies with emphasis on soybeans. In: Nutman, P. S. (ed.). Symbiotic Nitrogen Fixation in Plants. Cambridge University Press. Cambridge.

Hubbe11, D. H. 1976. Plant roots and biological nitrogen fixation. Soil Crop Sci. Soc. Florida 36: 37-40.

Jenny, H. and K. Grossenbacher. 1963. Root-soil boundary zones as seen in the electron microscope. Soil Sci. Soc. Proc. 27: 273-277.

Juniper, B. E. and R. M. Roberts.1966. Polysaccharide synthes is and the fine structure of root cells. Res. Hicrosc. Soc. 85 : 63-72.

Kass, D. L., M. Drossdoff and M. Alexander. 1971. Nitrogen fixation by Azotobacter paspali in association with bahia grass (Paspalum notatum). Soil Sci. Soc. Am. Proc. 35: 286-289.

Keleti, G. and W. H. Lederer. 1974. Handbook of Micromethods for the Biological Sciences. Van Nostrand Reinhold Co. N. Y. $166 \mathrm{pp}$.

Krieg, N. R. 1977. Taxonomic studies of Spirizzom Zipoferum. Basic Life Science 9: 463-472.

Lakshmi, V., A. Satyanarayana Rao, K. Vijayalakshmi, II. L. Kumari, K. V. B. R. Tilak and N. S. Subba-Rao. 1977. Establishnent and survival of Spirizzum Lipoferum. Proc. Ind. Acad. Sci. 86B: 397-404.

Lisker, N. and N. Retig. 1974. Detection of polygalacturonase and pectin lyase isoenzyme in polyacrylamide gel. Chron. 7522: 245-249.

Lowry, 0. H., N. J. Rosebrough, A. L. Fair and R. J. Randoll. 1951. Protein measurenent with Fol in phenol reagent. J. Biol. Cher. 193: 265-275.

Luft, J. H. 1961. Improvements of epoxy resin methods. J. Biophys. Biochim. Cytol. 9: 407-414. 
Lund, B. M. and L. W. Mapson. 1971. Stimulation by Emwinia carotovora of the synthesis of ethylene in cauliflower tissue. Biochem. J. 119: 251-263.

Marriel, I. E. and J. C. Cruz. 1977. Increased $\mathrm{N}_{2}$-fixation $\left(\mathrm{C}_{2} \mathrm{H}_{2}\right.$ reduction) in field grown maize by herbicide treatment. Int1. Symp. on the Limitations and Potentials of Biological Nitrogen Fixation in the Tropics. Universidad de Brasilia. Brazil, 1977.

McCoy, E. 1932. Infection of Bacterium radicicola in relation to the microchemistry of the hosts' cell wall. Proc. Roy. Soc. (Lond.). B. Biol. Sci. 110: 510-533.

Mollenhauer, H. H. and D. J. Morre'. 1966. Golgi apparatus and plant secretion. Ann. Rev. Plant Physiol. 17: 27-46.

Morre'. D. and H. Mollenhauer. 1967. Golgi apparatus mediated polysaccharide secretion by outer root cap cells of Zea mays L: Kinetics and secretory pathway. Planta 74: 286 .

Musse11, H. L. and L. Strand. 1976. Pectic enzymes: Involvement and pathogenesis and possible relevance to tolerance and specificity. In: Solheim, B. and J. Raa (eds.). Host-Pathogen Interaction. Universitetsforlagen. Norway. $487 \mathrm{pp}$.

Napoli, C., F. B. Dazzo and D. H. Hubbe11. 1975. Production of celiulose microfibrils by Rhizobium. Appl. Microbiol. 30: 123-132.

Nery, M., F. T. V. Abrantes, 0. dos Santos and J. Dobereiner. 1977. Nitrogen fixation ( $\mathrm{C}_{2} \mathrm{H}_{2}$ reduction) in wheat. Int?. Symp. on the Limitations and Potentials of Biological Nitrogen Fixation in the Tropics. Universidad de Brasilia. Brazi1, 1977.

Neyra, C. A. and J. Dobereiner. 1977. Nitrogen fixation in grasses. Advances in Agronomy 29: 1-38.

Neyra, C. A., J. Dobereiner, R. Lalande and R. Knowles. 1977. Denitrification by $\mathrm{N}_{2}$-fixing Spirizzum lipoferum. Can. J. Microbiol. 23: 300-305.

Northcote, D. H. and J. D. Pickett-Heaps. 1966. A function of the Golgi apparatus in polysaccharide synthesis and transport in the root cap cells of wheat. Biochem. J. 98: 159-167. 
Okon, Y., S. L. Albrecht and R. H. Burris. 1976a. Factors affecting growth and nitrogen fixation of Spirizzum Zipoferum. J. Bacterio1. 127: 1248-1254.

Okon, Y., S.L. Albrecht and R. H. Burris. 1976b. Carbon and amronia metabolism of Spirizzum Zipojemom. J. Bacteriol. 128: 592-597.

Okon, Y., S. L. Albrecht and R. H. Burris. 1977. Methods for growing Spirizzum Zipoferum and for counting it in pure culture and in association with plants. Appl. Environ. llicrobiol. 33: 85-87.

01d, K. M. and T. H. Nicholson. 1975. Electron microscopy of the nicrobial colonization of roots of sand dune grasses. Hew Phytol. 74: 51-58.

Page, W. S. and H. L. Sadoff. 1975. Relationship between calciun and uronic acids in the encystment of Azotobacter vinezandii. J. Bacteriol. 122: 145-151.

Pate, J. L. and E. J. Ordal. 1967. Fine structure of Chondrococcus columnaris. III. The surface layers of Chondrococous columaris. J. Cel1 Biol. 35: 37-51.

Patriquin, D. G. and J. Dobereiner. 1977. Bacteria in the endorhizosphere of maize in Brazil. Int1. Symp. on the Limitations and Potentials of Biological Nitrogen Fixation in the Tropics. Universidad de Brasilia. Brazi1, 1977.

Patriquin, D. G., F. I1. I1. llagalhaes, C. A. Scott and J. Dobereiner. 1978. Infection of field grown maize in Rio de Janeiro by Azospirizzum. Steenbock-Kettering Int1. Symp. on Nitrogen Fixation. University of Wisconsin-lladison. June, 1978.

Pedersen, W. L., K. Chakrabarty, R. V. Klucas and A. K. Vidaver. 1978. Nitrogen fixation (C2/H2 reduction) associated with roots of winter wheat and sorghim in Nebraska. Appl. Environ. Microbio1. 35: 129-135.

Pereira, P. A., C. A. Neyra and J. Dobereiner. 1977. Nitrogenase activity, assimilation of $\mathrm{N}_{3}^{-}$and denitrification in Brachiaria cores. Intl. Symp. on the Limitations and Potentials of Biological Nitrogen Fixation in the Tropics. Universidad de Brasilia. Brazil, 1977.

Reynolds, E. S. 1963. The use of lead citrate at high pH as electron opaque stain for electron microscopy. J. Ce11 Biol. 17: 208-212.

Rovira, A. D. 1969. Plant root exudates. Bot. Rev. 35: 35-59. 
Rovira, A. D. and R. C. Campbe11. 1974. Scanning electron microscopy of nicroorganisms on the roots of wheat. Microbial. Ecol. 1: 15-23.

Ruschel, A. P., Y. Henis and E. Salati. 1975. Nitrogen-15 tracing of $\mathbb{N}_{2}$ fixation with soil grown sugar cane seedlings. Soil Biol. Biochem. 7: 181-182.

Sampaio, M. J. A, L. de Vasconcelos and J. Dobereiner. 1978. Characterization of three groups of Spirizium Iipoferum Beijerinck. In: Granha1], U. (ed.). Environmental Role of $\mathrm{N}_{2}$-fixing Blue-green Algae and Asyrabiotic Bacteria. Ecol. Bu11. NFR (Stockholm) 26: 364-365.

Schroder, M. 1932. Die assirnilation des lufstickstoffs durch einege bakterien. Zentralb1. Bacteriol. Parasitknde. 85: $178-212$.

Schroth, M. N. and D. C. Hildebrand. 1964. Influence of plant exudates on root infecting fungi. Ann. Rev. Phytopath. 2: $101-132$.

Scott, C. A., F. II. M. Mlagalhaes, V. L. dos Santos Divan and D. B. Scott. 1977. Numbers of Azospirizzum spp. associated with the roots of field grown maize. Intl. Symp. on the Limitations and Potentials of the Biological Witogren Fixation in the Tropics. Universidad de Brasilia. Brazil, 1977.

Sing, V. 0. and M. N. Schroth. 1977. Bacteria-plant surface interactions: Active inmobilization of saprophytic bacteria in plant leaves. Science 197: 759-761.

Slankis, V. 1973. Hornonal relationships in mycorrhizal development. In: Marks, G. C. and T. Kozlowski (eds.). Ectomycorrhizae: Their Ecology and Physiolngy. Acad. Press. N. Y. p. 237-298.

Sloger, C. and L. D. Owens. 1976. Nitrogen fixation by a teriperate corn-Spirillum association. Intl. Symp. on $\mathrm{N}_{2}$ Fixation. Salamanca, Spain, 1976.

Smith, R. L., J. H. Bouton, S. C. Schank, K. H. Quesenberry, M. E. Tyler, J. R. Milam, M. H. Gaskins and R. C. Litte11. 1976. Nitrogen fixation in grasses inoculated with Spixilzum Iipoferum. Science 193: 1003-1005.

Spurr, A. R. 1969. A low viscosity epoxy resin embedding medium for electron microscopy. J. U1trastruc. Res. 26: 31-43.

Stephen, G. J. and R. K. S. Wood. 1974. Release of enzymes from cell walls by an endopectatetranselininase. Nature 251: 358. 
Strand, L. I.., C. Rechtoris and H. Musse11. 1976. Polygalacturonase release cell wall-bound proteins. Plant Physiol. 58: 722-725.

Streeter, J. G. and M. E. Bosler. 1976. Carbohydrates in soybean nodules: Identification of compounds and possible relationships to nitrogen fixation. Plant Sci. Letters 7: $321-329$.

Subba-Rao, W. S., K. V. B. R. Tilak, M. L. Kuriari and C. S. Singh. 1978. Response of crops to Spirizlum Zipoferwm inoculation. Steenbock-Kettering Intl. Symp. on Nitrogen Fixation. University of Wisconsin-Madison. June, 1978.

Tarrand, J. J., N. R. Krieg and J. Dobereiner. 1978. Taxonomic study of Spimizlum lipofermm group, with description of a new genus, Azospirizlum gen. nov. and two species, Asospirillum lipoferm (Beijerinck) comb. nov. and Azospirizlum brasilense sp. nov. Can. J. Microbiol. 24: $967-980$.

Taylor, G. S. and D. Parkinson. 1961. Growth of saprophytic fungi on root surfaces. Plant Soil 15: 261-267.

Tien, T. M., M. H. Gaskins, D. H. Hubbell and M. Umali-Garcia. 1978. Why does inoculation with Azospirizlum brasizense (Spirizzon lipoferum) increase yield of grasses. Steenbock-Kettering Int1. Symp. on Nitrogen Fixation. University of Wisconsin-Madison. June, 1978.

Tinker, P. B. H. and F. E. Sanders. 1975. Rhizosphere microorganisms and plant nutrition. Soil Sci. 119: 363-368.

Tjepkema, J. and P. van Berkum. 1977. Acetylene reduction by soil cores of maize and sorghum in Brazil. Appl. Environ. Nicrobiol. 33: 626-629.

Tu, J. C. 1976. Cytoplasmic changes during and after infection of soybean nodule cells with rhizobia. Phytopath. 66: 1065-1071.

Tyler, M. E., J. R. Milam and D. A. Zuberer. 1977. Taxonomy of the diazotroph of tropical grasses called Spirizzum lipofemm. Int1.. Symp. on the Limitations and Potentials of Biological Nitrogen Fixation in the Tropics. Universidad de Brasilia. Brazil, 1977.

Uma 1i-Garcia, M., D. H. Hubbell and M. H. Gaskins. 1978. Process of infection of Panicum maximum by Spirizlum lipoferum. In: Franha11, U.(ed.). Environnental Role of NitrogenFixing Blue-green Algae and Asymbiotic Bacteria. Ecol. Bu11. NFR (Stockholm) 26: 373-379. 
Wheeler, C. T. and A. C. Lawrie. 1976. Nitrogen fixation in root nodules of alder and pea in relation to the supply of photosynthate assimilates. In: Nutman, P. S. (ed.). Symbiotic Nitrogen Fixation in Plants. Cambridge University Press. Cambridge. $584 \mathrm{pp}$.

Yoshida, T. and R. R. Ancajas. 1971. Nitrogen fixation by bacteria in the root zone of rice. Proc. Soit Sci. Soc. Am. 35: 156-157.

Yoshida, T. and R. R. Ancajas. 1973. The fixation of atmospheric nitrogen in the rice rhizosphere. Soil Biol. Biochem. 5: 153-155. 


\section{BIOGRAPHICAL SKETCH}

Mercedes U. Garcia (née Mercedes M. Umali) was born to Lorenza C. Maligaya and Jose C. Umali in September 24, 1936. She finished her elementary education in her home town, Calaca, Batangas, Philippines, in 1951 and her secondary education in the City of Manila in 1955. She obtained her B. S. in Agriculture degree (Honors' Curriculum), major in Plant Breeding, from the University of Philippines at Los Banos in 1960. She was awarded a Graduate Research Fellowship in 1962 - 1964 which enabled her to finish the requirments for an M. S. in Forest Genetics. She has been employed at the University of the Philippines since 1960, and currently holds a faculty position in the same institution. She is married to Benjamin M. Garcia, Sr., with whom she has six children, namely, Vener, Benjie, Mina, Joven, Ruben and Bien. 
I certify that I have read this study and that in my opinion it conforms to acceptable standards of scholarly presentation and is fully adequate, in scope and quality, as a dissertation for the degree of Doctor of Philosophy.

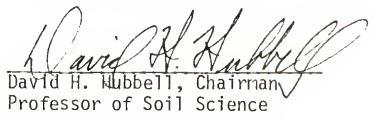

I certify that I have read this study and that in my opinion it conforms to acceptable standards of scholarly presentation and is fully adequate, in scope and quality, as a dissertation for the degree of Doctor of Philosophy.

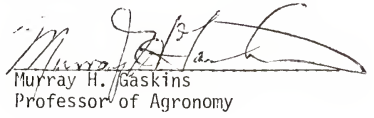

I certify that I have read this study and that in my opinion it conforms to acceptable standards of scholarly presentation and is fully adequate, in scope and quality, as a dissertation for the degree of Doctor of Philosophy.

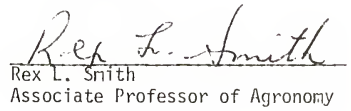

I certify that I have read this study and that in my opinion it conforms to acceptable standards of scholarly presentation and is fully adequate, in scope and quality, as a dissertation for the degree of Doctor of Philosophy.

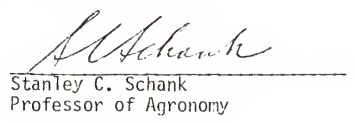


I certify that I have read this study and that in my opinion it conforms to acceptable standards of scholarly presentation and is fully adequate, in scope and quality, as a dissertation for the degree of Doctor of Philosophy.

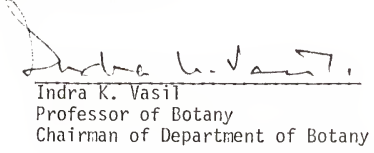

This dissertation was subritted to the Graduate Faculty of the College of Agriculture and to the Graduate Council, and was accepted as partial fulfillment of the requirements for the degree of Doctor of Philosophy.

December, 1978

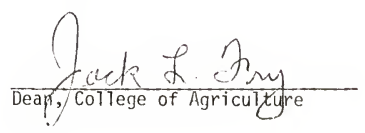

Dean, Graduate School 